ARTICLE

Received 20 Apr 2016 | Accepted 16 Nov 2017 | Published 9 Jan 2017 DOl: 10.1038/ncomms13946 OPEN

\title{
The transcription factor EPAS1 links DOCK8 deficiency to atopic skin inflammation via IL-31 induction
}

Kazuhiko Yamamura1,2, Takehito Uruno ${ }^{1,3}$, Akira Shiraishi ${ }^{1}$, Yoshihiko Tanaka4 ${ }^{4}$ Miho Ushijima', Takeshi Nakahara², Mayuki Watanabe, Makiko Kido-Nakahara², Ikuya Tsuge ${ }^{5}$, Masutaka Furue ${ }^{2}$ \& Yoshinori Fukui 1,3

Mutations of DOCK8 in humans cause a combined immunodeficiency characterized by atopic dermatitis with high serum IgE levels. However, the molecular link between DOCK8 deficiency and atopic skin inflammation is unknown. Here we show that CD4 ${ }^{+} \mathrm{T}$ cells from DOCK8-deficient mice produce large amounts of IL-31, a major pruritogen associated with atopic dermatitis. IL-31 induction critically depends on the transcription factor EPAS1, and its conditional deletion in CD4 ${ }^{+}$T cells abrogates skin disease development in DOCK8deficient mice. Although EPAS1 is known to form a complex with aryl hydrocarbon receptor nuclear translocator (ARNT) and control hypoxic responses, EPAS1-mediated I/31 promoter activation is independent of ARNT, but in collaboration with SP1. On the other hand, we find that DOCK8 is an adaptor and negative regulator of nuclear translocation of EPAS1. Thus, EPAS1 links DOCK8 deficiency to atopic skin inflammation via IL-31 induction in CD4 ${ }^{+} \mathrm{T}$ cells.

\footnotetext{
${ }^{1}$ Division of Immunogenetics, Department of Immunobiology and Neuroscience, Medical Institute of Bioregulation, Kyushu University, 3-1-1 Maidashi, Higashi-ku, Fukuoka 812-8582, Japan. ${ }^{2}$ Department of Dermatology, Graduate School of Medical Sciences, Kyushu University, 3-1-1 Maidashi, Higashi-ku, Fukuoka 812-8582, Japan. ${ }^{3}$ Research Centre for Advanced Immunology, Kyushu University, 3-1-1 Maidashi, Higashi-ku, Fukuoka 812-8582, Japan. ${ }^{4}$ Department of Functional Bioscience, Section of Infection Biology, Fukuoka Dental College, 2-15-1 Tamura, Sawara-ku, Fukuoka 814-0175, Japan.

${ }^{5}$ Department of Pediatrics, School of Medicine, Fujita Health University, 1-98 Dengakugakubo, Kutsukake-cho, Toyoake 470-1192, Japan. Correspondence and requests for materials should be addressed to Y.F. (email: fukui@bioreg.kyushu-u.ac.jp).
} 
omozygous and compound heterozygous mutations in DOCK8 cause a combined immunodeficiency characterized by recurrent viral infections, early onset malignancy and atopic dermatitis $(\mathrm{AD})^{1-5}$. As patients with DOCK8 mutations have elevated serum IgE levels, this disorder has been classified as a form of autosomal recessive hyper IgE syndrome (HIES) ${ }^{4,5}$. DOCK8 is an evolutionarily conserved guanine nucleotide exchange factor (GEF) for Cdc42 (ref. 6). Accumulating evidence indicates that human patients with DOCK8 mutations have morphological and functional abnormalities of leukocytes ${ }^{1,7-9}$. In addition, the important roles of DOCK8 in leukocytes have been demonstrated using animal models. For example, $N$-ethyl$N$-nitrosourea-mediated mutagenesis in mice has shown that DOCK8 regulates immunological synapse formation in $B$ cells, and is required for development or survival of memory $\mathrm{CD}^{+} \mathrm{T}$ cells, natural killer $\mathrm{T}$ cells and type 3 innate lymphoid cells ${ }^{9-14}$. On the other hand, by generating DOCK8-deficient (Dock $8^{-/-}$) mice, we and others have revealed that DOCK8 is essential for interstitial migration of dendritic cells ${ }^{6,15}$. However, the molecular link between DOCK8 deficiency and atopic skin inflammation is not defined.

Interleukin 31 (IL-31) is a recently discovered cytokine that is related to the IL-6 cytokine family in terms of its structure and receptor complex ${ }^{16,17}$. IL-31 is expressed by activated $\mathrm{T}$ cells and is preferentially produced by $\mathrm{T}$ helper type 2 (Th2) $\mathrm{CD}^{+}{ }^{+} \mathrm{T}$ cells. IL-31 signals via a heterodimeric receptor composed of IL-31 receptor A (IL31RA; also known as GPL or GLM-R) and oncostatin M receptor (OSMR) ${ }^{16,17}$, both of which are expressed in various cell-types, including neurons of dorsal root ganglia ${ }^{17-19}$. Mice treated with intradermal injection of IL-31 and transgenic mice overexpressing IL-31 exhibit scratching behaviour and develop severe dermatitis ${ }^{16,19}$. In addition, in patients with AD, IL-31 is expressed by cutaneous lymphocyte antigen-positive skin homing $\mathrm{CD}_{4}{ }^{+} \mathrm{T}$ cells ${ }^{18,20}$, and serum IL-31 levels have been shown to correlate with the disease activity ${ }^{21}$. Moreover, a phase 1 clinical trial has proven the apparent anti-pruritic effect of IL-31 receptor antibody in $\mathrm{AD}^{22}$. Thus, IL-31 is a $\mathrm{T}$-cell derived cytokine closely associated with pruritus in $\mathrm{AD}$ patients.

Endothelial PAS domain protein 1 (EPAS1) is a member of basic-helix-loop-helix/PAS domain containing transcription factors, and has a high homology to hypoxiainducible factor (HIF)-1 $\alpha$, thus termed HIF-2 $\alpha$ (ref. 23). Like HIF-1 $\alpha$, EPAS1 forms a complex with aryl hydrocarbon receptor nuclear translocator (ARNT; also know as HIF-1 $\beta$ ) and transactivates target genes to respond to environmental stressors such as hypoxia ${ }^{24-26}$. Although the role of EPAS1 in the immune system is unexplored, gene network analysis suggests that EPAS1 is a direct target of signal transducer and activator of transcription-6 (STAT6) and acts as a hub protein in IL-4-mediated transcription circuitries in human $\mathrm{CD}^{+} \mathrm{T}$ cells ${ }^{27,28}$. Therefore, EPAS1 may have a specific role in differentiation and effector functions of Th2 cells. In this study, we identify EPAS1 as an important transcription factor for IL-31 induction in $\mathrm{CD}^{+}{ }^{+} \mathrm{T}$ cells. Interestingly, EPAS1 mediates Il31 promoter activation independently of ARNT, but in collaboration with the transcription factor SP1. On the other hand, we find that DOCK8 negatively regulates nuclear translocation of EPAS1 and its deletion leads to severe skin disease in a mouse model. Our results thus indicate that EPAS1 links DOCK8 deficiency to atopic skin inflammation via IL-31 induction in $\mathrm{CD} 4{ }^{+} \mathrm{T}$ cells.

\section{Results}

Production of IL-31 by Dock8 ${ }^{-/-} \mathrm{CD}^{+} \mathrm{T}$ cells. To examine the role of DOCK8 in antigen-specific $\mathrm{T}$ cell responses, we developed Dock $8^{-/-}$mice expressing OTII T-cell receptor (TCR) that recognizes OVA peptide (OVA323-339) presented by $\mathrm{I}-\mathrm{A}^{\mathrm{b}}$ molecules on the genetic background of $\mathrm{C} 57 \mathrm{BL} / 6$ mice (designated Dock $8^{-/-}$OTII Tg mice). Flow cytometric analyses revealed that $\mathrm{T}$ cell development in the thymus occurred normally even in the absence of DOCK8 (Fig. 1a). Although the proportion and the number of $\mathrm{T}$ cells in the spleen were reduced in Dock $8^{-/-}$OTII Tg mice (Fig. 1a,b), as reported in Dock $8^{-I-}$ non-TCR Tg mice ${ }^{6}$, the majority of peripheral $\mathrm{T}$ cells were $\mathrm{CD} 4{ }^{+} \mathrm{T}$ cells expressing $\mathrm{V} \alpha 2^{+} \mathrm{V} \beta 5^{+}$OTII TCR, irrespective of DOCK 8 expression (Fig. 1a). These CD $4^{+} \mathrm{T}$ cells proliferated comparably when stimulated with OVA peptide in the presence of $\mathrm{I}-\mathrm{A}^{\mathrm{b}}$-expressing C57BL/6 spleen cells (Fig. 1c). Interestingly, however, we found that the level of Il31 transcript markedly increased in $\mathrm{CD}^{+} \mathrm{T}$ cells from Dock $8^{-/-}$OTII Tg mice $24 \mathrm{~h}$ after stimulation, as compared with that in Dock $8^{+/-}$ OTII $\mathrm{Tg} \mathrm{CD} 4{ }^{+} \mathrm{T}$ cells (Fig. 1d). In contrast, Il2 and Il4 gene expressions in stimulated $\mathrm{CD} 4{ }^{+} \mathrm{T}$ cells were unchanged between Dock $8^{+/-}$and Dock $8^{-/-}$OTII Tg mice (Fig. 1d). This effect of DOCK8 deficiency on Il31 induction became more evident when activated $\mathrm{CD} 4{ }^{+} \mathrm{T}$ cells were recovered $96 \mathrm{~h}$ after antigen stimulation, and re-stimulated with anti-CD3e antibody. Indeed, compared with the level of unstimulated control samples, Il31 transcript increased 4,369-fold in Dock $8^{-1-}$ OTII Tg CD4 ${ }^{+} \mathrm{T}$ cells at $3 \mathrm{~h}$ after secondary stimulation, and this value was 49.0 times higher than that of Dock $8^{+/-}$OTII Tg CD ${ }^{+}$T cells (Fig. 1e). Consistent with this finding, ELISA revealed that $\mathrm{CD} 4{ }^{+} \mathrm{T}$ cells from Dock $8^{-/-}$ OTII Tg mice produced larger amounts of IL-31 on TCR stimulation (Fig. 1f). These results indicate that DOCK8 negatively regulates antigen-induced IL-31 production by $\mathrm{CD} 4^{+} \mathrm{T}$ cells.

Although IL-31 has been implicated in pruritus in $\mathrm{AD}$, Dock $8^{-/-}$OTII Tg mice showed neither skin inflammation nor IgE elevation (Supplementary Fig. 1). To assess whether $\mathrm{CD} 4{ }^{+} \mathrm{T}$ cells from Dock $8^{-/-}$OTII Tg mice have the potential to induce itch, we adoptively transferred them into mice ubiquitously expressing OVA under the control of the cytomegalovirus immediate early enhancer-chicken $\beta$-actin hybrid promoter (designated CAG-OVA mice). As a result, antigenstimulated CD4 ${ }^{+} \mathrm{T}$ cells from Dock $8^{-I_{-}}$, but not Dock $8^{+/-}$, OTII Tg mice induced scratching behaviour in CAG-OVA mice at $5-7 \mathrm{~h}$ after transfer (Fig. $1 \mathrm{~g}$ ). These results indicate that Dock $8^{-/-} \mathrm{CD} 4^{+} \mathrm{T}$ cells are capable of inducing itch when they are activated in vivo.

Atopic skin inflammation in Dock8 ${ }^{-/-}$AND Tg mice. To examine whether the effect of DOCK8 deficiency could be extended to other $\mathrm{CD} 4{ }^{+} \mathrm{T}$ cells with different antigen specificity, we developed Dock $8^{-/-}$mice expressing AND TCR on the genetic background of C57BL/6 mice (designated Dock $8^{-/-}$ AND Tg mice). AND TCR is a product of artificial $\alpha \beta$-chain combination, which recognizes moth cytochrome $\mathrm{C}$ peptide

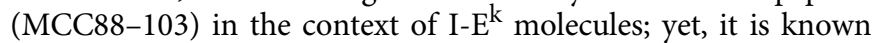
that $\mathrm{CD} 4{ }^{+} \mathrm{CD} 8{ }^{+}$thymocytes expressing AND are also selected to mature in the presence of $\mathrm{I}^{-\mathrm{A}^{\mathrm{b}}}$ molecules $^{29}$. As seen in Dock $8^{-/-}$OTII Tg mice, $\mathrm{CD} 4{ }^{+} \mathrm{T}$ cells normally developed in Dock $8^{-1-}$ AND Tg mice and responded to MCC peptide in the presence of $\mathrm{I}_{-} \mathrm{E}^{\mathrm{k}}$-expressing B10.BR spleen cells (Supplementary Fig. 2a-c). In addition, $\mathrm{CD} 4{ }^{+} \mathrm{T}$ cells from Dock $8^{-/}$AND Tg mice produced large amounts of IL-31 on secondary stimulation (Supplementary Fig. 2d). Thus, DOCK8 
a

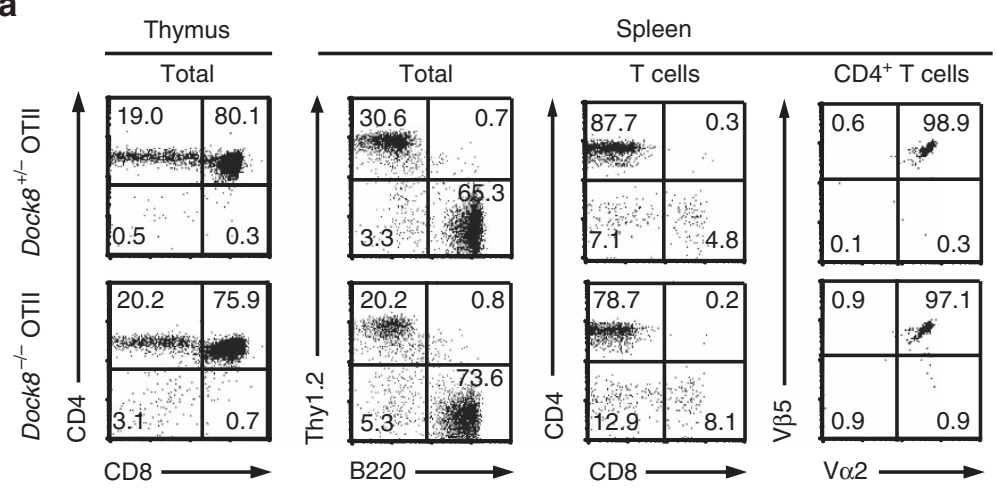

b
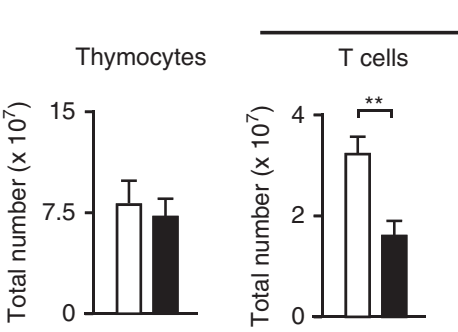

Spleen
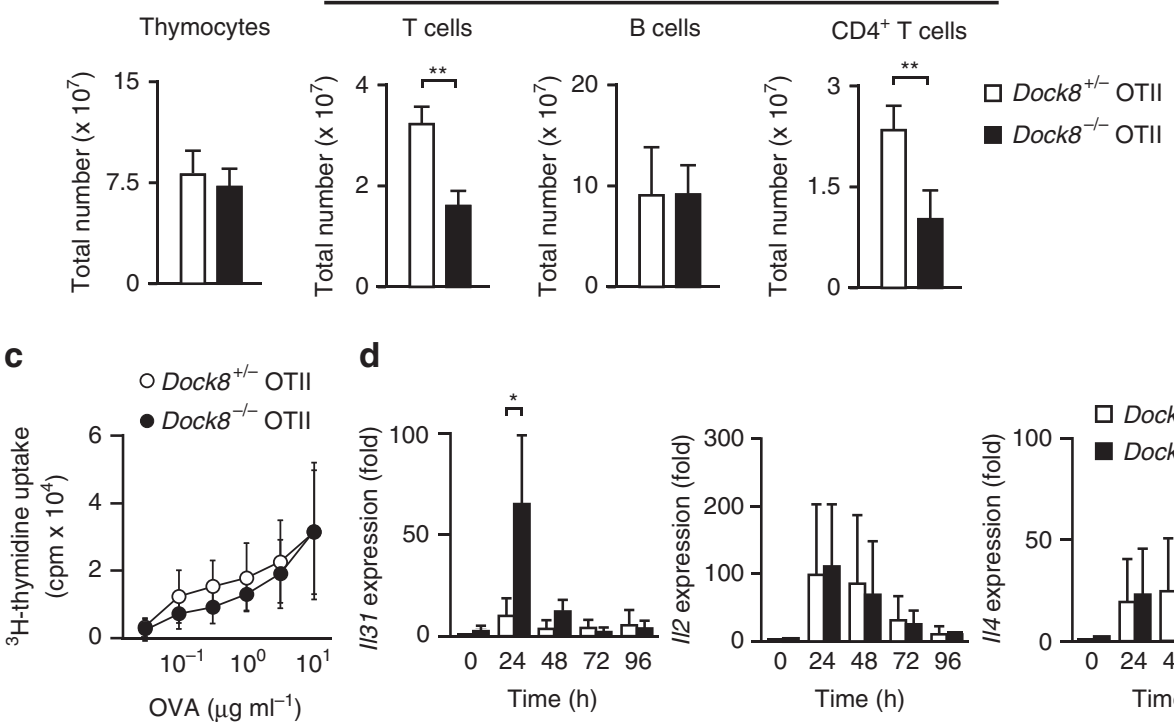

d

e

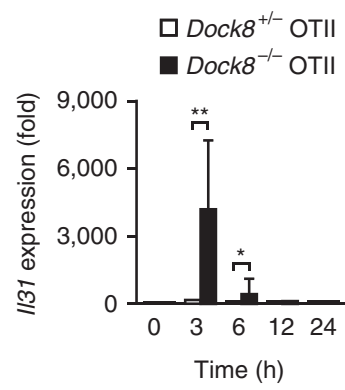

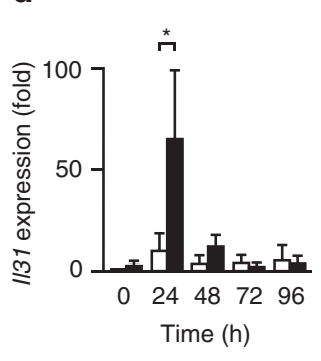

f

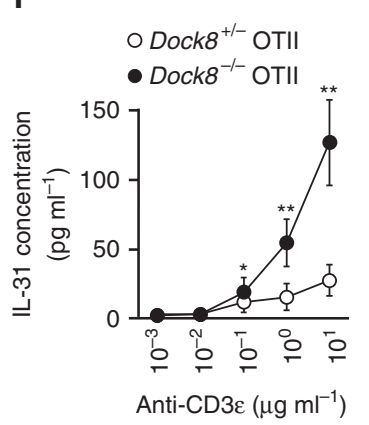

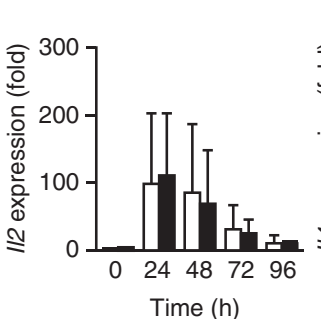

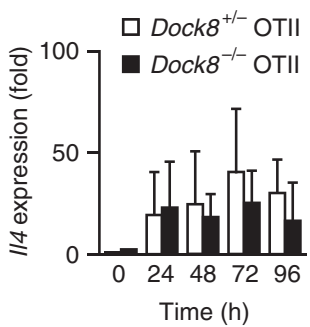

g $\square$ Dock8 $^{+/-}$OTII $\rightarrow$ CAG-OVA

- Dock8 $8^{-/}$OTII $\rightarrow$ CAG-OVA

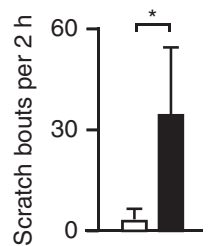

Figure 1 | DOCK8 negatively regulates IL-31 induction in CD4 ${ }^{+}$T cells. (a,b) Flow cytometric analyses of thymocytes and spleen cells from 6- to 8-weekold Dock8 $8^{+/-}$and Dock8 $8^{-1-}$ OTII Tg mice. The numerals in quadrants indicate the percentage of each subset of leukocytes. Data are expressed as mean \pm s.d. of 5 mice per group. ${ }^{\star} P<0.01$ (two-tailed Student's $t$-test). See Supplementary Fig. 10 for FACS gating strategy. (c) Antigen-specific proliferation of $\mathrm{CD} 4{ }^{+}$T cells from Dock8 ${ }^{+/-}$and Dock8 $8^{-/-}$OTII Tg mice. Data are expressed as mean \pm s.d. of 12 samples per group. (d) Induction of cytokine gene expression in CD4 ${ }^{+}$T cells from Dock8 ${ }^{+/-}$and Dock8 ${ }^{-/-}$OTII Tg mice after primary stimulation with OVA peptide. Expression (fold increase) is relative to that of unstimulated Dock $8^{+/-}$samples. Data are expressed as mean \pm s.d. of 8 samples per group. ${ }^{\star} P<0.05$ (two-tailed Student's $t$-test). (e) $/ 131$ gene expression in CD4 ${ }^{+}$T cells from Dock $8^{+/-}$and Dock $8^{-/-}$OTII Tg mice after secondary stimulation with anti-CD3 $\varepsilon$ and anti-CD28 antibodies. Expression (fold increase) is relative to that of Dock $8^{+/-}$samples without secondary stimulation. Data are expressed as mean \pm s.d. of 10 samples per group. ${ }^{\star} P<0.05 ;{ }^{\star \star} P<0.01$ (two-tailed Student's t-test). (f) ELISA showing increased IL-31 production by Dock8 ${ }^{-/}-\mathrm{OTII}^{*} \mathrm{Tg}$ CD4 ${ }^{+}$ T cells after secondary stimulation. Data are mean \pm s.d. of 9 samples per group. ${ }^{\star} P<0.05 ;{ }^{\star}{ }^{\star} P<0.01$ (two-tailed Student's $t$-test). (g) Induction of itch in CAG-OVA mice by adoptive transfer of activated CD4 ${ }^{+}$T cells from Dock8 ${ }^{-/-}$, but not Dock8 ${ }^{+/-}$, OTII Tg mice. Data are expressed as mean \pm s.d. of four mice per group. ${ }^{\star} P<0.05$ (two-tailed Mann-Whitney test). 
generally acts as a negative regulator for IL-31 induction in $\mathrm{CD} 4{ }^{+} \mathrm{T}$ cells, irrespective of their antigen specificity.

Surprisingly, we found that Dock $8^{-/-}$AND Tg mice developed severe skin inflammation by the age of 14-15 weeks. The severity of dermatitis was grossly assessed by the SCORAD (human SCORing Atopic Dermatitis) that was modified for the use in mice ${ }^{30,31}$. Irrespective of the sex of mice, skin phenotype first appeared 7-8 weeks after birth, generally worsened with the age, and was never observed in Dock $8^{+/-}$AND Tg littermate mice (Fig. 2a). Consistent with this, the proportion of $\mathrm{CD} 44^{+} \mathrm{CD} 6 \mathrm{~L}^{-}$activated $\mathrm{CD}^{+} \mathrm{T}$ cells gradually increased in Dock $8^{-/}$AND Tg mice with the age (Fig. 2b). In addition, the serum concentrations of IgE, but not IgG $2 \mathrm{~b}$, increased in Dock $8^{-/}-$AND Tg mice at 12 and 18 weeks old (Fig. 2c). Dock $8^{-/-}$AND Tg mice exhibited intense scratching behaviour at 12 and 18 weeks old (Fig. 2d), indicating that this skin inflammation was pruritic. Histological and immunohistochemical analyses of the skin from Dock $8^{-/-}$AND Tg mice revealed acanthosis, hyperkeratosis and mild spongiosis with massive infiltration of $\mathrm{CD} 4^{+} \mathrm{T}$ cells a

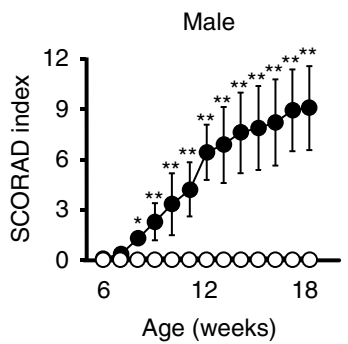

d

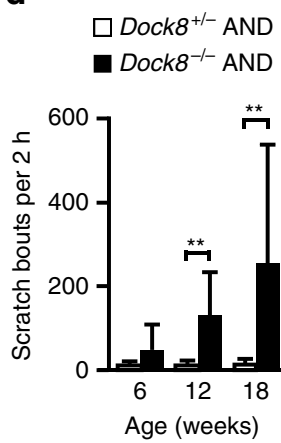

b

O Dock8 ${ }^{+/-}$AND

- Dock8 ${ }^{-/-}$AND

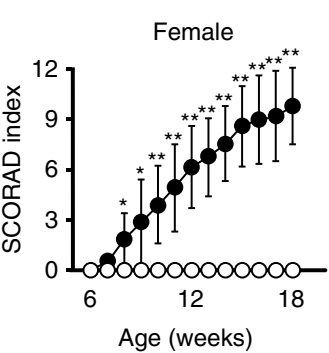

$\square$ Dock8 ${ }^{+/-}$AND

- $D o c k 8^{-1-}$ AND

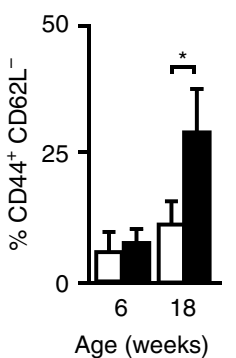

C

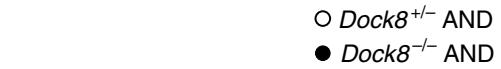

\section{e}

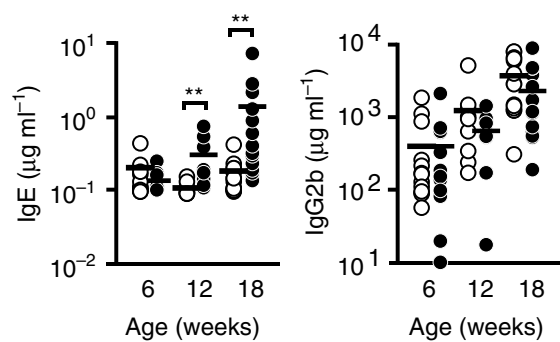

f

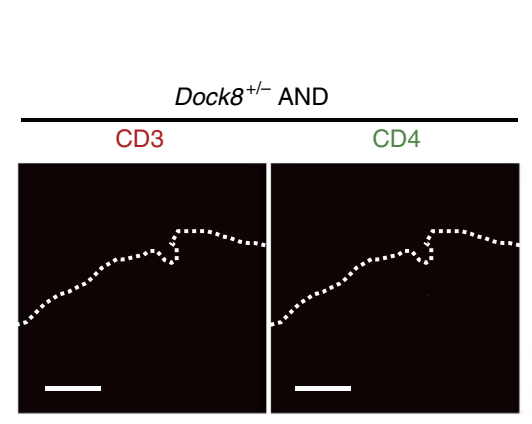

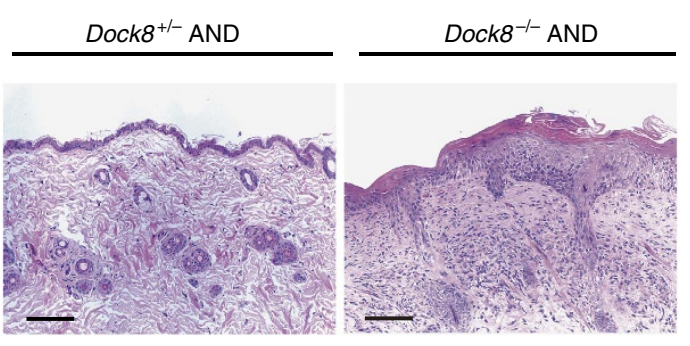

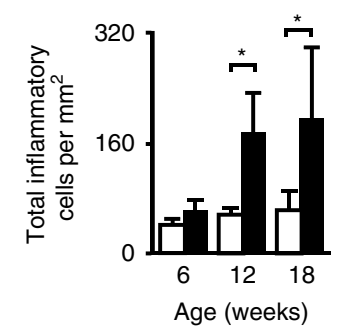

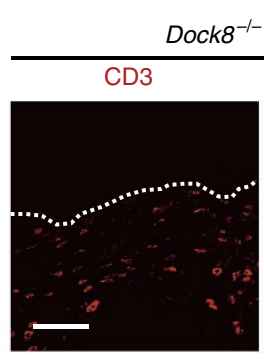

g

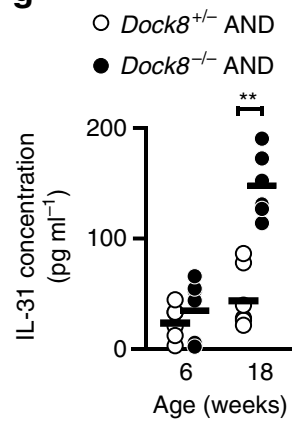

Figure 2 | Development of atopic skin inflammation in Dock8 ${ }^{-/-}$AND Tg mice. (a) SCORAD index of Dock8 $8^{+/}$(male, $n=20 ;$ female, $\left.n=15\right)$ and Dock8 ${ }^{-1}$ - (male, $n=20$; female, $n=15$ ) AND Tg littermates. Data are expressed as mean \pm s.d. ${ }^{\star} P<0.05$; ${ }^{\star \star} P<0.01$ (two-tailed Student's $t$-test). (b) The percentage of $\mathrm{CD} 44^{+} \mathrm{CD}_{22} \mathrm{~L}^{-}$activated CD4 ${ }^{+}$T cells in total PLN CD4 ${ }^{+}$T cells from Dock8 ${ }^{+/-}$and Dock8 ${ }^{-/-}$AND Tg littermates at 6 and 18 weeks old. Data are expressed as mean \pm s.d. of 4 mice per group. ${ }^{\star} P<0.05$ (two-tailed Mann-Whitney test). (c) Serum concentrations of IgE and lgG $2 \mathrm{~b}$ in Dock $^{+/-}$and Dock8 ${ }^{-/-}$AND Tg mice at $6(n=13), 12(n=8$ or 9$)$ and $18(n=14)$ weeks old. The lines indicate the mean values. ${ }^{\star \star} P<0.01$ (two-tailed Mann-Whitney test). (d) Comparison of scratching bouts between Dock8 ${ }^{+/-}$and Dock $8^{-/}$- AND Tg mice at $6(n=8), 12(n=6)$ and $18(n=8)$ weeks old. Data are expressed as mean \pm s.d. ${ }^{\star \star} P<0.01$ (two-tailed Mann-Whitney test). (e) Haematoxylin and eosin staining of the skin from 18-week-old littermates. Scale bars, $100 \mu \mathrm{m}$. The number of inflammatory cells per $\mathrm{mm}^{2}$ was compared between Dock $8^{+/-}$and Dock $8^{-/-}$AND Tg mice. In each experiment, three fields were examined per mouse. Data are expressed as mean \pm s.d. of four mice group. ${ }^{\star} P<0.05$ (two-tailed Mann-Whitney test). (f) Immunofluorescence staining showing infiltration of CD4 ${ }^{+}$T cells in the skin of Dock8 ${ }^{-/}$- AND Tg mice. Scale bars, $50 \mu \mathrm{m}$. (g) Serum concentrations of IL-31 in Dock8 ${ }^{+/-}$and Dock8 ${ }^{-/-}$AND Tg mice at $6(n=6)$ and $18(n=6)$ weeks old. The lines indicate the mean values. ${ }^{\star \star} P<0.01($ two-tailed Student's t-test). 


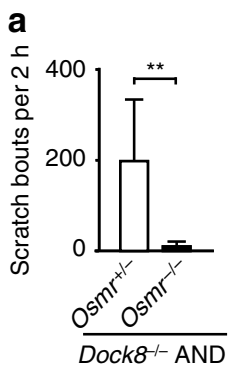

b
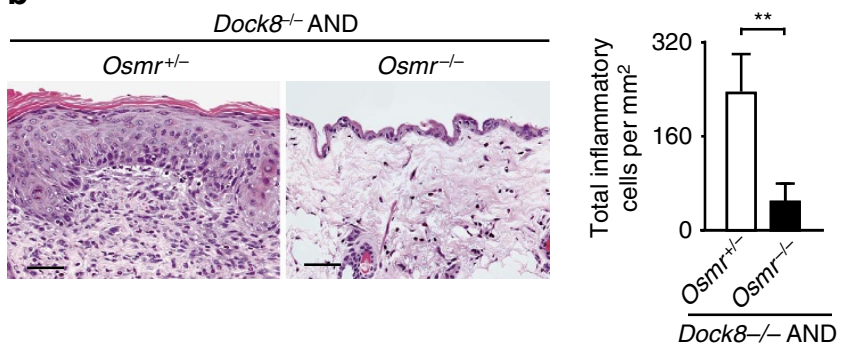

Figure 3 | OSMR-dependent skin disease development in Dock8 ${ }^{-/-}$AND Tg mice. (a) Comparison of scratching bouts between Osmr $+/-$and $\mathrm{Osmr}^{-/-}$Dock8 ${ }^{-/-}$AND Tg mice at 18 weeks old. Data are expressed as mean \pm s.d. of 6 mice per group. ${ }^{\star \star} P<0.01$ (two-tailed Student's $t$-test). (b) Haematoxylin and eosin staining of the skin from 18-week-old littermates. Scale bars, $50 \mu \mathrm{m}$. The number of inflammatory cells per mm ${ }^{2}$ was compared between $\mathrm{Osmr}^{+/-}$and Osmr ${ }^{-/}-$Dock8 ${ }^{-/}-$AND Tg mice at 18 weeks old. In each experiment, 3 fields were examined per mouse. Data are expressed as mean \pm s.d. of 5 mice per group. ${ }^{\star \star} P<0.01$ (two-tailed Mann-Whitney test).

and, to lesser extent, eosinophils (Fig. 2e,f and Supplementary Fig. 3). The skin-infiltrating $\mathrm{CD} 4^{+} \mathrm{T}$ cells in Dock8 $8^{-/-} \mathrm{AND}$ Tg mice mainly expressed Th2 cytokines including Il31 (Supplementary Fig. 4). More importantly, Dock $8^{-/-}$AND Tg mice showed significant increase in serum IL-31 levels at 18 weeks, compared with those of Dock ${ }^{+/-}$AND Tg mice (Fig. 2g).

IL-31 transmits the signals via a heterodimeric receptor composed of IL31RA and OSMR ${ }^{16,17}$. To examine whether IL-31-mediated signals are involved in the disease development, we deleted the expression of OSMR in Dock $8^{-/-}$AND Tg mice by crossing them with OSMR-deficient mice $\left(\mathrm{Osmr}^{-9-}\right)^{32}$. OSMR deficiency did not affect serum IL-31 levels (Supplementary Fig. 5). However, in AND Tg mice lacking both DOCK8 and OSMR (Dock8 $-1-\mathrm{Osmr}^{-9}$ AND Tg), scratching bouts per $2 \mathrm{~h}$ were reduced to $11.5 \pm 9.3$, as compared with $200.8 \pm 135.8$ in Dock8 ${ }^{-/}-$Osmr ${ }^{+/}-$AND Tg mice (Fig. 3a), and they did not develop skin inflammation (Fig. 3b). So far, no evidence has been provided that oncostatin M is involved in itch induction. Therefore, these results suggest that Dock $8^{-/-}$AND Tg mice spontaneously develop atopic skin inflammation through the mechanism dependent on IL-31 signalling.

Identification of EPAS1 as a regulator for IL-31 induction. To explore the underlying mechanism of IL-31 overproduction by Dock $8^{-/-} \mathrm{CD} 4{ }^{+} \mathrm{T}$ cells, we first performed microarray analysis, and found that 856 genes were expressed at higher levels in Dock $8^{-/-}$AND Tg CD ${ }^{+}$T cells than Dock8 ${ }^{+/-}$AND Tg controls after antigen stimulation. These included 40 genes encoding putative transcriptional factors (Supplementary Table 1), one of which was EPAS1. When pMX vector encoding EPAS1-IRES-GFP was expressed in WT CD4 ${ }^{+} \mathrm{T}$ cells by retroviral transfer, TCR stimulation-induced Il31 gene expression was significantly augmented, compared with that of the control expressing GFP alone (Fig. 4a). On the other hand, induction of $\mathrm{Il} 31$ gene expression in Dock8 ${ }^{-/-}$AND CD4 ${ }^{+}$ $\mathrm{T}$ cells was markedly suppressed by knocking down Epas1 gene expression using siRNA (Fig. 4b). Similar results were obtained when Il31 gene expression was analysed in $\mathrm{CD}^{+} \mathrm{T}$ cells from Dock $8^{-/-}$AND Tg mice lacking EPAS1 expression in a CD4 ${ }^{+}$ $\mathrm{T}$ cell-specific manner (CD4-Cre ${ }^{+}$Epas $1^{\text {lox }}$ lox Dock8 ${ }^{-/-}$AND Tg mice) (Fig. 4c). More importantly, scratching behaviour and skin disease development as well as an increased serum IL-31 level were cancelled in all CD4-Cre ${ }^{+}$Epas $1^{\text {lox } / l o x}$ Dock8 $8^{-/-}$ AND Tg mice tested (Fig. 4d-f). Thus, EPAS1 functions as a master regulator for IL-31 induction in $\mathrm{CD}^{+} \mathrm{T}$ cells and is required for development of atopic skin inflammation in Dock $8^{-/-}$AND Tg mice.

EPAS1 acts with SP1 in Il31 promoter activation. Having identified EPAS1 as a key molecule for Il31 induction, we next examined how EPAS1 acts in Il31 promoter activation. For this purpose, we created reporter construct containing Il31 promoter sequence $(-1,367$ to -1$)$ and the luciferase gene. When this reporter construct was expressed in mouse embryonic fibroblasts (MEFs), Il31 promoter activation was induced in the presence of WT EPAS1 (Fig. 5a). However, the expression of EPAS1 mutants lacking $\mathrm{N}$-terminal or $\mathrm{C}$-terminal activation domain $(\triangle \mathrm{N}-\mathrm{TAD}$ and $\triangle \mathrm{C}-\mathrm{TAD})$ failed to induce promoter activation (Fig. 5a). EPAS1 is known to form a complex with ARNT via PAS-B domain ${ }^{26}$. Surprisingly, however, deletion of neither PAS-B nor bHLH did affect Il31 promoter activation (Fig. 5a). Consistent with this, EPAS1-mediated Il31 promoter activation occurred normally even when Arnt gene was knocked down (Fig. 5b). By deleting Il31 promoter region, we identified the critical region for EPAS1-mediated transactivation (Fig. 5c), which included a consensus SP1-binding sequence GGCC at the position from -118 to -115 (Fig. 5d). Indeed, electrophoretic mobility shift assay (EMSA) showed that SP1 bound to this sequence (Fig. 5e). When this GGCC sequence was mutated to AAGT, EPAS1-mediated Il31 promoter activation was almost completely lost (Fig. 5d). More importantly, EPAS1-mediated Il31 promoter activation significantly diminished by knocking down Sp1 gene expression (Fig. 5b). In addition, chromatin immunoprecipitation (ChIP) assay revealed that SP1 was recruited to Il31 promoter in activated $\mathrm{CD}^{+} \mathrm{T}$ cells from Dock $8^{-/-}$AND Tg mice and its recruitment was significantly reduced in the absence of EPAS1 (Fig. 5f). Collectively, these results indicate that EPAS1 induces Il31 promoter activation, independently of ARNT, but in collaboration with SP1.

DOCK8 negatively regulates nuclear translocation of EPAS1. EPAS1 mediates promoter activation of target genes in the nucleus after translocation from the cytoplasm. As DOCK8 is also expressed in MEFs (Supplementary Fig. 6), we prepared WT and Dock $8^{-/-}$MEFs, and examined the effect of DOCK8 deficiency on subcellular localization of EPAS1 by staining them with anti-EPAS1 antibody. The specificity of this antibody was verified by lack of the reactivity to Epas $1^{-/-}$MEFs (Supplementary Fig. 7). We found that, while EPAS1 translocated to the nucleus in both types of MEFs in response to hypoxia, nuclear localization of EPAS1 in Dock $8^{-/-}$MEFs was markedly augmented even under the steady state (Fig. 6a). This effect of 
a

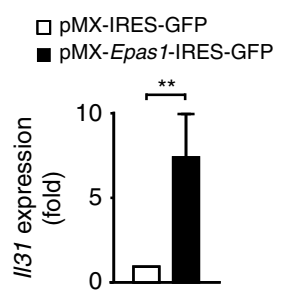

d

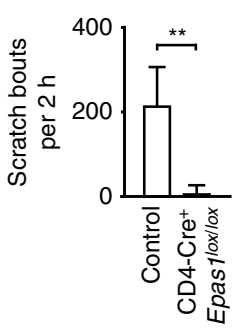

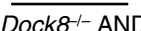

b

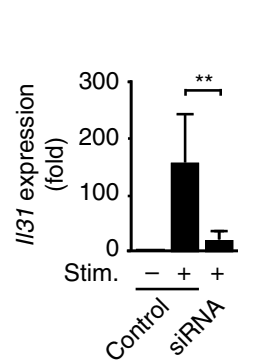

e

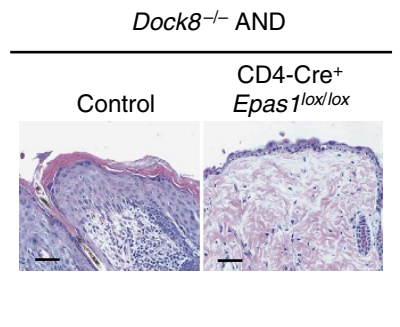

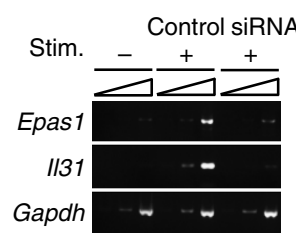

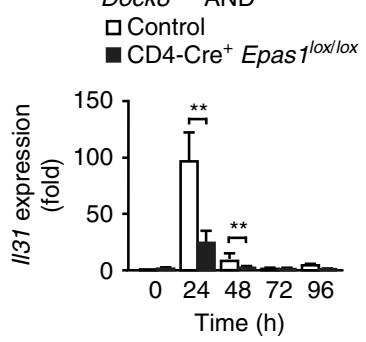

Figure 4 | EPAS1 acts as a regulator for IL-31 induction during skin inflammation. (a) Induction of II31 gene expression in WT CD4 ${ }^{+} \mathrm{T}_{\text {cells }}$ by overexpression of EPAS1. Expression (fold increase) is relative to that of the control vector (pMX-IRES-GFP). Data are expressed as mean $\pm \mathrm{s}$.d. of eight samples per group. ${ }^{\star \star} P<0.01$ (two-tailed Mann-Whitney test). (b) Effect of Epas1 knock down on II31 gene expression in CD4 ${ }^{+} \mathrm{T}$ cells from Dock8 ${ }^{-} /-$ AND Tg mice. Expression (fold increase) is relative to that of the unstimulated samples. Data are expressed as mean \pm s.d. of 6 samples per group. ${ }^{\star \star} P<0.01$ (two-tailed Student's $t$-test). Amplification increased by 2 cycles, from the left to the right, starting at 34 cycles for Epas1 and II31, or at 29 cycles for Gapdh. (c) Effect of genetic inactivation of Epas1 on I/31 gene expression in CD4 ${ }^{+}$T cells from Dock8 ${ }^{-/}$- AND Tg mice after primary stimulation with MCC peptide. Expression (fold increase) is relative to that of the unstimulated control samples. Data are expressed as mean \pm s.d. of 9 samples per group.

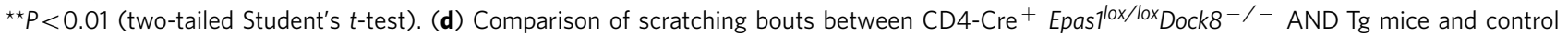
littermates at 14 weeks old. Data are expressed as mean \pm s.d. of five mice per group. ${ }^{\star \star} P<0.01$ (two-tailed Student's $t$-test). (e) Haematoxylin and eosin staining of the skin from 14-week-old littermates. Scale bars, $50 \mu \mathrm{m}$. The number of inflammatory cells per mm ${ }^{2}$ was compared between CD4-Cre ${ }^{+}$ Epas1 ${ }^{10 x / l o x}$ Dock8 $8^{-/}$AND Tg mice and control littermates. In each experiment, 3 fields were examined per mouse. Data are expressed as mean \pm s.d. of 4 mice group. ${ }^{\star} P<0.05$ (two-tailed Mann-Whitney test). (f) Serum concentrations of IL-31 in CD4-Cre ${ }^{+}$Epas $7^{10 x / l o x}$ Dock ${ }^{-/-}$AND Tg mice ( $\left.n=4\right)$ and control littermates $(n=4)$ at 14 weeks old. The lines indicate the mean values. ${ }^{\star} P<0.05$ (two-tailed Mann-Whitney test). In (c-f), CD4-Cre ${ }^{-}$ Epas7 ${ }^{\text {lox/lox }}$ Dock8 $^{-/-}$AND Tg mice or CD4-Cre ${ }^{+}$Epas $^{\text {lox } / w}$ Dock8 ${ }^{-/-}$AND Tg mice were used as controls.

DOCK8 deficiency was cancelled when WT DOCK8 was stably expressed in Dock $8^{-/-}$MEFs (Fig. 6b,c). Similar results were obtained by expressing the DOCK8 mutant $(\Delta \mathrm{DHR} 2)$ lacking DOCK homology region (DHR)-2 domain critical for Cdc42 activation ${ }^{6}$ (Fig. 6b,c). However, the expression of DOCK8 mutant $(\Delta \mathrm{N})$ lacking the N-terminal 527 amino acid residues in Dock $8^{-/-}$MEFs failed to suppress nuclear accumulation of EPAS1 (Fig. 6b,c), indicating that the $\mathrm{N}$-terminal region of DOCK8 is important for controlling subcellular localization of EPAS1.

MST1 is a serine/threonine kinase that has been implicated in $\mathrm{T}$ cell adhesion, migration, proliferation and apoptosis ${ }^{33}$. During the course of screening for DOCK8-binding proteins, we found that DOCK8 bound to MST1 through the N-terminal region when overexpressed in human embryonic kidney 293T (HEK-293T) cells (Fig. 6d, left). Similar association was observed with the activated $\mathrm{CD}^{+}{ }^{+} \mathrm{T}$ cells (Fig. 6e). When DOCK8, MST1 and EPAS1 were co-expressed in HEK-293T cells, EPAS1 and MST1 were co-immunoprecipitated, irrespective of the presence of DOCK8 (Fig. 6d, right). This raised the possibility that DOCK8 might regulate subcellular localization of EPAS1 through the association with MST1. Indeed, we found that nuclear translocation of EPAS1 was significantly augmented by knocking down Mst1 gene expression (Fig. 6f). More importantly, knock down of Mst1 markedly induced Il31 gene expression in $\mathrm{CD}^{+} \mathrm{T}$ cells from Dock $8^{+/-}$AND Tg mice (Fig. 6g). These results indicate that DOCK8-MST1 axis negatively regulates IL-31 induction by inhibiting nuclear translocation of EPAS1.

Role of DOCK8 and EPAS1 in human $\mathrm{CD}^{+} \mathrm{T}$ cells. Finally, we examined the role of DOCK8 and EPAS1 in human $\mathrm{CD} 4{ }^{+} \mathrm{T}$ cells obtained from healthy controls and $\mathrm{AD}$ patients. In $\mathrm{CD}^{+}{ }^{+} \mathrm{T}$ cells from healthy controls, knock down of DOCK8 gene markedly increased IL31 gene expression (Fig. 7a), indicating that DOCK8 also acts as a negative regulator for IL-31 induction in human $\mathrm{CD}^{+}{ }^{+} \mathrm{T}$ cells. Consistent with this, a DOCK8-deficient patient ${ }^{34}$ exhibited an elevated serum IL-31 level, as seen in conventional AD patients (Fig. 7b). Although DOCK8 expression was comparable between healthy controls and AD patients (Supplementary Fig. 8), TCR stimulation-induced expression of IL31, but not IL2, was much higher in $\mathrm{CD}^{+}{ }^{+} \mathrm{T}$ cells from $\mathrm{AD}$ patients than those from healthy controls (Fig. 7c). Importantly, induction of IL31 gene expression was also cancelled when EPAS1 gene expression was knocked down in $\mathrm{CD} 4{ }^{+} \mathrm{T}$ cells from $\mathrm{AD}$ patients (Fig. 7d). These results indicate that EPAS1-dependent pathway also operates for IL-31 induction in $\mathrm{CD} 4^{+} \mathrm{T}$ cells from $\mathrm{AD}$ patients. To further examine the role of EPAS1 in 
a

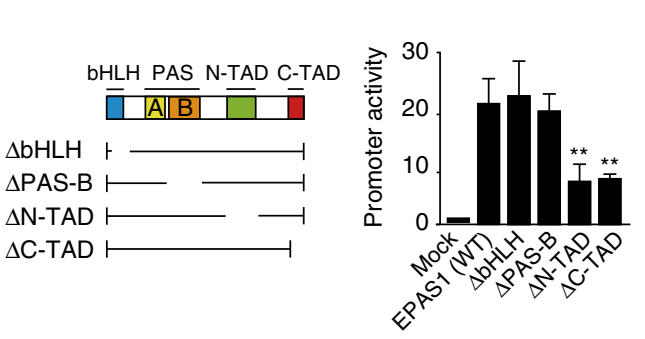

b

d

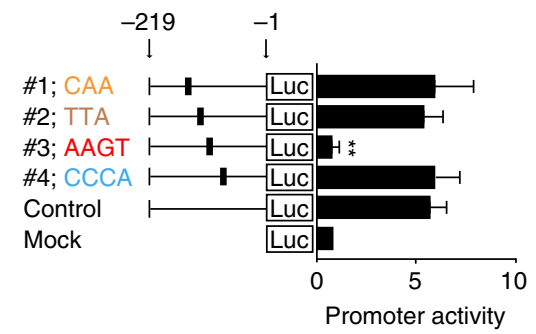

GGCTGGCAACCTTTTGAAAATGTTTTCTGGAGAAAAGCTGA
$-135 \quad-121$
GCAATGTTTTGCCATGGGCGGCCTTTGATCTGCTTCCTC
\#1 \#2 \#3 \#4
ATGACAACCCTTTATATATTGCCTGGTGGCCATGGCGAACA

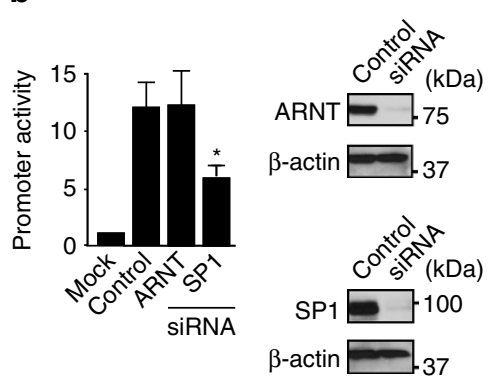

e

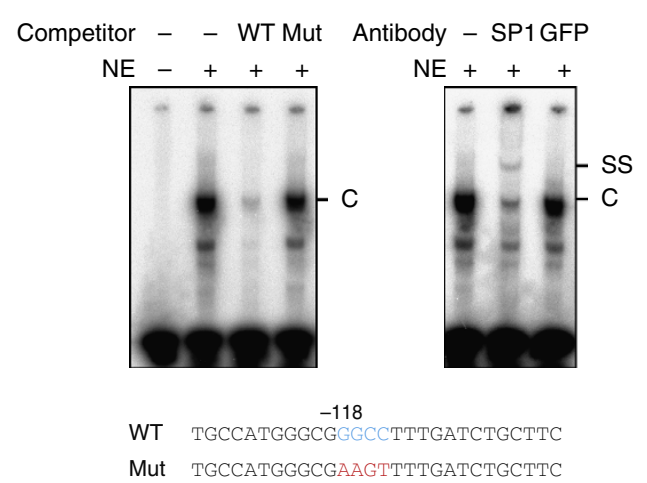

C

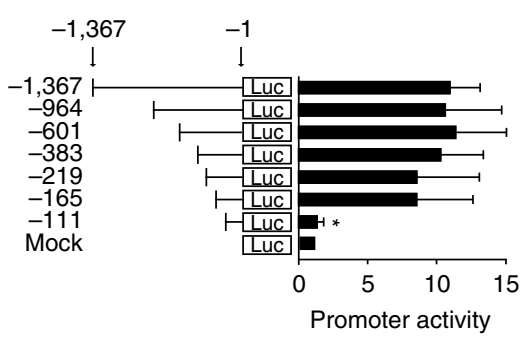

f
Dock8 ${ }^{-/-}$AND Tg

$\square$ CD4-Cre ${ }^{-}$Epas1 $1^{10 x / 10 x}$

- CD4-Cre ${ }^{+}$Epas $1^{10 x / 10 x}$

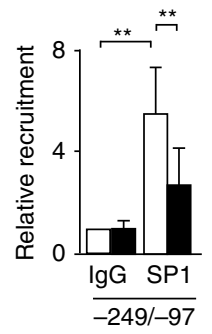

Figure 5 | EPAS1 induces I/31 promoter activation in collaboration with SP1. (a) EPAS1-dependent I/31 promoter activation. Schematic representation of EPAS1 mutants used in this study is shown. Data are expressed as mean \pm s.d. of 5 independent experiments. ${ }^{\star \star} P<0.01$ (one-way analysis of variance (ANOVA) followed by post hoc Bonferroni test). (b) Requirement for SP1, but not ARNT, in EPAS1-mediated II31 promoter activation. Data are expressed as mean \pm s.d. of three independent experiments. ${ }^{\star} P<0.05$ (one-way ANOVA followed by post hoc Bonferroni test). Knock down efficacy was checked by Western blot analyses. See Supplementary Fig. 11a for uncropped scans of the Westen blot. (c,d) Identification of the critical region of II31 promoter for EPAS1-mediated transactivation by deletion (c) and site-directed mutagenesis (d) studies. Data are expressed as mean $\pm \mathrm{s}$.d. of three independent experiments. ${ }^{\star} P<0.05$; ${ }^{\star} P<0.01$ (one-way ANOVA followed by post hoc Bonferroni test). (e) EMSA showing SP1 binding to the specific II31 promoter sequence. The ' $C$ ' or 'SS' indicates the band corresponding to SP1-DNA complex or super-shift, respectively. NE, nuclear extracts. Data are representative of 4 independent experiments. (f) ChIP assays showing recruitment of SP1 to $/ / 31$ promoter in Dock8 ${ }^{-/-}$AND Tg CD4 ${ }^{+}$T cells and its reduction in the absence of EPAS1. Data (mean \pm s.d., $n=7$ ) are expressed as the relative recruitment after normalization of the level of control samples (CD4-Cre ${ }^{-}$Epas $7^{10 x / l o x}$ samples precipitated with rabbit $\operatorname{lgG}$ ) to an arbitrary value of $1 .{ }^{\star \star} P<0.01$ (two-tailed Student's $t$-test). In a-d, promoter activity is expressed as the relative index after normalization of the luciferase activity of pGL4.10-/131 alone (Mock) to an arbitrary value of 1.

IL-31 induction, we treated $\mathrm{CD} 4{ }^{+} \mathrm{T}$ cells from $\mathrm{AD}$ patients with two inhibitors, FM19G11 and HIFVII. FM19G11 is not a direct inhibitor of EPAS1, but it is known to suppress EPAS1 gene expression by acting on undefined target ${ }^{35}$. Indeed, the expression level of EPAS1 was markedly reduced when human $\mathrm{CD}^{+} \mathrm{T}$ cells were treated with FM19G11 (Fig. 7e). In agreement with genetic data, we found that FM19G11 treatment ablated TCR stimulation-induced expression of IL31, but not IL2, in $\mathrm{CD}^{+} \mathrm{T}$ cells from $\mathrm{AD}$ patients (Fig. 7f). However, such inhibitory effect was not observed with HIFVII (Fig. 7f), which binds to PAS-B domain of EPAS1 and inhibits its association with $\mathrm{ARNT}^{26,36}$ (Supplementary Fig. 9). Thus, in $\mathrm{CD}^{+} \mathrm{T}$ cells from $\mathrm{AD}$ patients, EPAS1 also regulates IL-31 induction independently of ARNT binding.

\section{Discussion}

IL-31 is a T-cell derived cytokine implicated in pruritus in $\mathrm{AD}$, yet the mechanism controlling IL-31 production remains unknown. Here we have identified EPAS1 as a key transcription factor that regulates IL-31 induction in $\mathrm{CD}^{+}{ }^{+} \mathrm{T}$ cells in both mice and humans. Although EPAS1 is known to form a complex with ARNT and control various biological functions such as vascular remodelling, pulmonary development and skeletal growth $^{37-42}$, EPAS1 mediated Il31 promoter activation independently of ARNT, but in collaboration with SP1. A similar ARNT-independent and SP1-dependent promoter activation by EPAS1 was reported for a few genes such as copper-transporting ATPase (Atp7a) gene and blood coagulation factor VII $(f V I I)$ gene ${ }^{43,44}$. The precise mechanism by which SP1 potentiates EPAS1-mediated Il31 promoter activation remains to be determined. However, we found that SP1 recruitment to Il31 promoter was significantly reduced in EPAS1-deficient $\mathrm{CD}^{+}{ }^{+} \mathrm{T}$ cells. Therefore, it seems likely that EPAS1 recruits SP1 and other co-factors to form 'EPAS1 enhanceosomes' and alters the mode of transcription from a basal to an inducible state, as previously suggested ${ }^{45}$.

Homozygous and compound heterozygous mutations in DOCK8 cause a combined immunodeficiency characterized by recurrent viral infections, early onset malignancy and $\mathrm{AD}^{1-5}$. However, the molecular link between DOCK8 deficiency and atopic skin inflammation is poorly understood. In this study, we have shown that Dock $8^{-/}-\mathrm{CD} 4^{+} \mathrm{T}$ cells produce large amounts of IL-31 in a manner dependent on EPAS1. Consistent with this, a DOCK8-deficient patient ${ }^{34}$ exhibited increased serum IL-31. Mechanistically, we found that nuclear translocation of EPAS1 was significantly augmented in the absence of DOCK8. Although DOCK8 is a Cdc42-specific $\mathrm{GEF}^{6}$, rescue experiments revealed that the GEF activity of DOCK8 was not required in this process. Instead, DOCK8 
a

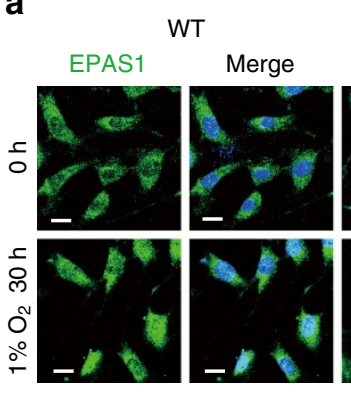

Dock8 ${ }^{-1-}$

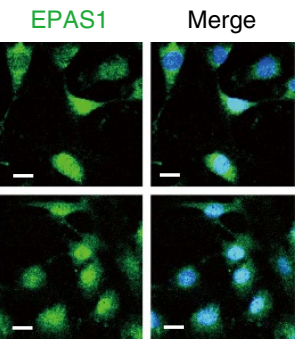

b

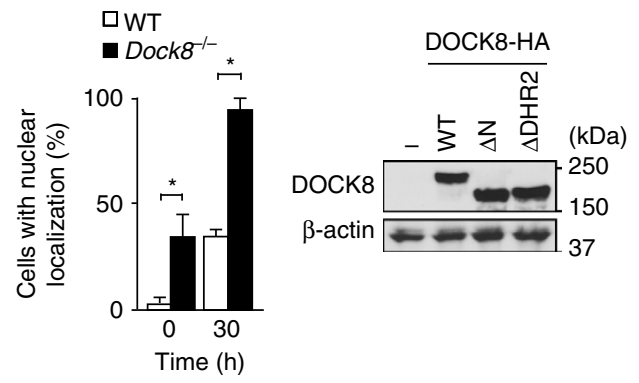

C

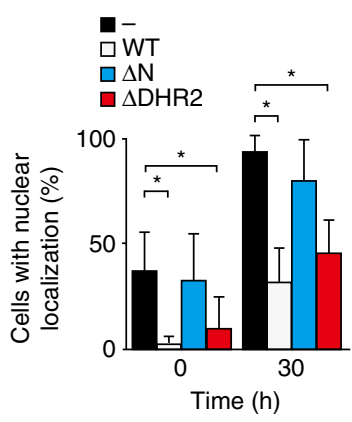

d
DOCK8-HA: WT $\triangle N$ WT $\triangle N$ MST1-FLAG: $-\quad++(\mathrm{kDa})$

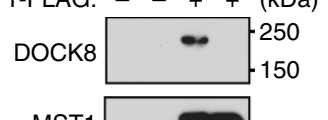

MST1 IP: FLAG (MST1)

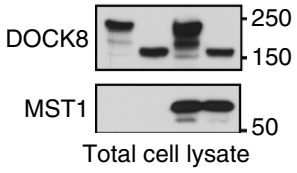

DOCK8-HA: ++++

MST1-V5: + - + EPAS1-FLAG: $-+++(\mathrm{kDa})$
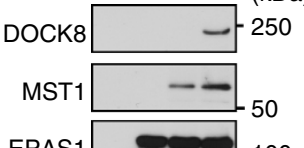

EPAS1 100 IP: FLAG (EPAS1)

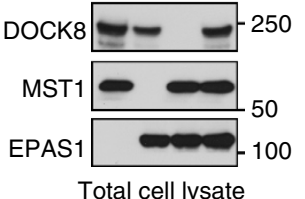

e

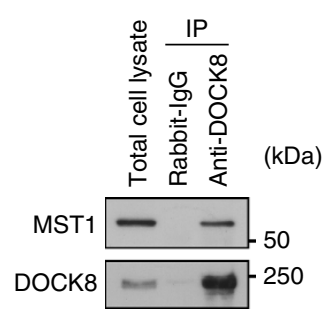

f

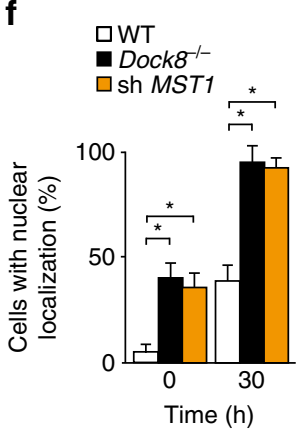

9

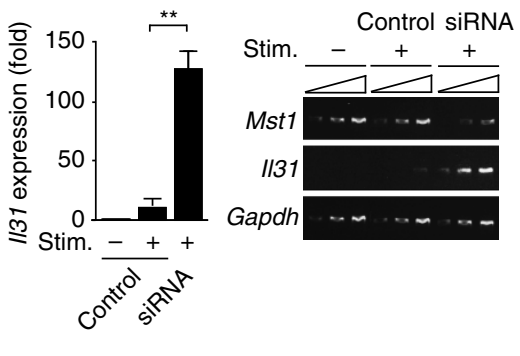

Figure 6 | DOCK8 regulates nuclear translocation of EPAS1 via MST1 interaction. (a) Immunofluorescence analyses for subcellular localization of EPAS1 in MEFs under steady and hypoxia conditions. DAPI was used to stain nuclei. Scale bars, $20 \mu \mathrm{m}$. The proportion of cells with nuclear localization of EPAS1 was compared between WT and Dock8 $8^{-/}$MEFs. In each experiment, 30 cells were counted per group. Data are expressed as mean \pm s.d. of 4 independent experiments. ${ }^{\star} P<0.05$ (two-tailed Mann-Whitney test). (b,c) Comparison of nuclear localization of EPAS1 between Dock8 ${ }^{-/}-M^{2}$ MFs and those stably expressing HA-tagged WT DOCK8 or its mutants ( $\triangle \mathrm{N}$ and $\triangle \mathrm{DHR} 2)$. Western blot analysis was performed with anti-HA and anti- $\beta$ actin antibodies. In each experiment, 30 cells were counted per group. Data are expressed as mean \pm s.d. of four independent experiments. ${ }^{\star} P<0.05$ (two-tailed Mann-Whitney test). (d) Formation of DOCK8-MST1-EPAS1 molecular complex in HEK-293T cells. $24 \mathrm{~h}$ after transfection of the expression plasmids in HEK-293T cells, cell extracts were subjected to immunoprecipitation and immunoblotting. Data are representative of three separate

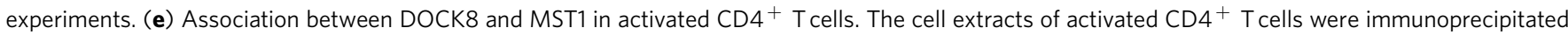
with anti-DOCK8 antibody or control rabbit IgG. Immunoblotting was carried out with anti-MST1 and anti-DOCK8 antibodies. Data are representative of three separate experiments. (f) Effect of Mst7 knock down on nuclear localization of EPAS1 in WT MEFs. In each experiment, 30 cells were counted per group. Data are expressed as mean \pm s.d. of four independent experiments. ${ }^{\star} P<0.05$ (two-tailed Mann-Whitney test). (g) Effect of Mst1 knock down on $1 / 31$ gene expression in CD4 ${ }^{+}$T cells from Dock8 ${ }^{+/}-$AND Tg mice. Expression (fold increase) is relative to that of the unstimulated samples. Data are expressed as mean \pm s.d. of 6 samples per group. ${ }^{\star \star} P<0.01$ (two-tailed Student's $t$-test). Amplification increased by 2 cycles, from the left to the right, starting at 34 cycles for Mst1 and II31 or at 29 cycles for Gapdh. See Supplementary Fig. 11b-d for uncropped scans of the westen blot.

acted as an adaptor and negatively regulated nuclear translocation of EPAS1 through the interaction with MST1. Interestingly, it has been reported that 7 of 9 patients with MST1 mutations had eczema or $\mathrm{AD}$-like skin disease ${ }^{46-48}$, raising the possibility that MST1 is also involved in IL-31 induction. Indeed, we found that Il31 gene expression markedly increased in CD4 ${ }^{+}$ T cells when Mst1 gene was knocked down. Our results thus define a previously unknown signalling cascade that links DOCK8 deficiency to IL-31 induction.

Although $\mathrm{CD} 4{ }^{+} \mathrm{T}$ cells from both Dock $8^{-/-}$AND Tg and Dock $8^{-/-}$OTII Tg mice produced IL-31 on stimulation with cognate antigens, only Dock $8^{-/-}$AND Tg mice spontaneously developed atopic skin disease. It is clear that $\mathrm{CD}^{+} \mathrm{T}$ cells play a major role in the disease development, 


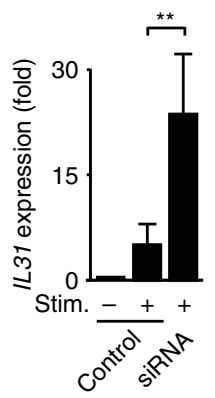

C

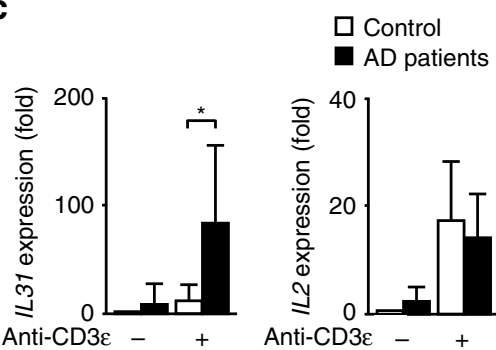

b

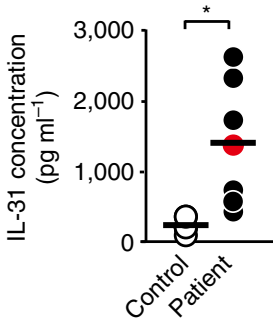

d
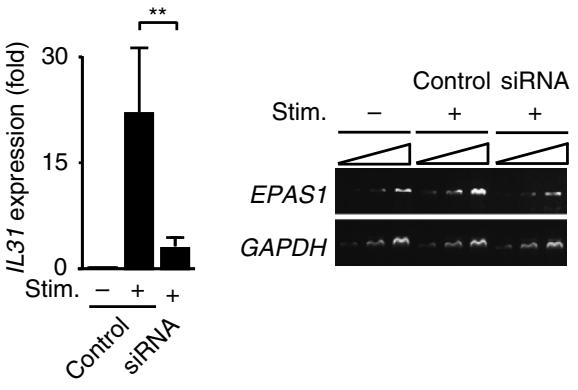

e

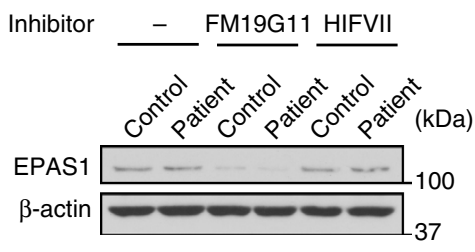

f

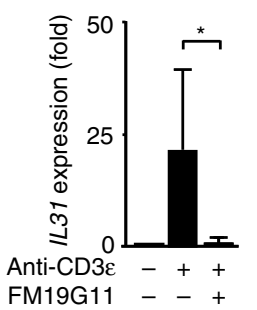

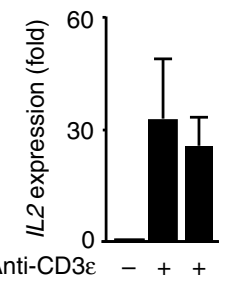

FM19G11 -++

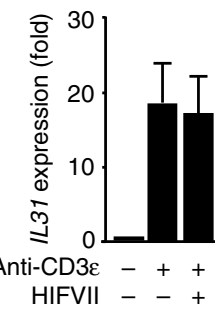

Figure 7 | Role of DOCK8 and EPAS1 in IL-31 induction in human CD4 ${ }^{+}$T cells. (a) Effect of DOCK8 knock down on TCR stimulation-induced IL31 gene expression in $\mathrm{CD}_{4}^{+} \mathrm{T}$ cells from healthy controls. Expression (fold increase) is relative to that of the unstimulated samples. Data are expressed as mean \pm s.d. of eight samples. ${ }^{\star \star} P<0.01$ (two-tailed Student's $t$-test). Amplification increased by 2 cycles, from the left to the right, starting at 34 cycles for DOCK8 or at 29 cycles for GAPDH. (b) Comparison of serum IL-31 concentrations between healthy controls $(n=6)$ and DOCK8-deficient patient $\left(n=1\right.$; red circle) or $A D$ patients $(n=6)$. The lines indicate the mean values. ${ }^{\star} P<0.05$ (two-tailed Student's $t$-test for comparison between $A D$ patients and healthy controls). (c) TCR stimulation-induced cytokine gene expression in CD4 ${ }^{+}$T cells from AD patients $(n=6)$ and healthy controls $(n=6)$. Expression (fold increase) is relative to that of unstimulated healthy controls. Data are expressed as mean \pm s.d. ${ }^{\star} P<0.05$ (two-tailed Mann-Whitney test).

(d) Effect of EPAS1 knock down on IL31 gene expression in CD4 ${ }^{+}$T cells from AD patients. Expression (fold increase) is relative to that of the unstimulated samples. Data are expressed as mean \pm s.d. of 6 samples. ${ }^{\star} P<0.01$ (two-tailed Mann-Whitney test). Amplification increased by 2 cycles, from the left to the right, starting at 34 cycles for EPAS1 or at 29 cycles for GAPDH. (e) Effect of on FM19G11 and HIFVII on EPAS1 expression in CD4 ${ }^{+}$T cells from $A D$ patients and healthy controls. Data are representative of three separate experiments. See Supplementary Fig. 11e for uncropped scans of the Westen blot. (f) Effect of FM19G11 $(n=6)$ and HIFVII $(n=3)$ on TCR stimulation-induced cytokine gene expression in CD4 ${ }^{+}$T cells from AD patients. Expression (fold increase) is relative to that of AD patient samples without stimulation. Data are expressed as mean \pm s.d. ${ }^{\star} P<0.05$ (two-tailed Student's $t$-test).

because all the phenotypes disappeared in Dock $8^{-/-}$AND Tg mice when EPAS1 expression was specifically deleted in $\mathrm{CD} 4^{+}$ $\mathrm{T}$ cells. The precise reason for this discrepancy is currently unknown. However, since $\mathrm{CD}^{+} \mathrm{T}$ cells from Dock8 $8^{-/-}$ OTII Tg mice also induced itch in vivo on transfer into CAG-OVA mice, antigen availability may be a determinant of the disease induction. Unlike OTII TCR, AND TCR is a product of artificial $\alpha \beta$-chain combinations, and recent evidence indicates that AND TCR has much higher 'self-reactivity' to I- $\mathrm{A}^{\mathrm{b}}$ molecules than OTII TCR ${ }^{49}$. Therefore, it might be possible that $\mathrm{CD}^{+} \mathrm{T}$ cells expressing AND TCR are continuously, albeit weakly, stimulated with self-peptide/I- $\mathrm{A}^{\mathrm{b}}$ complexes in vivo, and induce skin inflammation by producing IL-31 only when DOCK8 expression is lacking.

$\mathrm{AD}$ is a chronic inflammatory skin disease, and its prevalence is steadily increasing all over the world ${ }^{50}$. In this study, we have also shown that genetic or pharmacological inactivation of EPAS1 suppresses IL-31 induction in $\mathrm{CD}^{+} \mathrm{T}$ cells from $\mathrm{AD}$ patients. As DOCK8 expression is unchanged between $\mathrm{AD}$ patients and healthy controls, it is likely that DOCK8-independent, but EPAS1-dependent mechanism operates for IL-31 induction in AD patients. How EPAS1 is activated in $\mathrm{CD}^{+} \mathrm{T}$ cells from $\mathrm{AD}$ patients is currently unknown. However, recent evidence indicates that in human $\mathrm{CD} 4{ }^{+} \mathrm{T}$ cells, EPAS1 is a direct target of STAT6 and serves as a hub protein in IL-4-mediated transcription circuitries ${ }^{27,28}$. Therefore, it is highly conceivable that multiple genetic and environmental factors skewing Th2 differentiation could contribute to EPAS1 activation in AD patients. Whether particular cascades are involved in EPAS1 activation in $\mathrm{AD}$ patients would be an important issue that should be investigated in future studies. 
In conclusion, we have demonstrated that EPAS1 plays a key role in IL-31 induction in mice and humans with atopic skin inflammation. Thus, EPAS1 may be a therapeutic target for controlling IL-31-associated itch.

\section{Methods}

Mice. Dock $8^{-/-}$mice have been described previously ${ }^{6}$. Mice heterozygous for the mutant allele $\left(\right.$ Dock $8^{+/-}$) were backcrossed onto a C57BL/6 background for more than nine generations, and Dock ${ }^{+/-}$mice were crossed with AND TCR Tg mice or OTII TCR Tg mice to obtain Dock $8^{+/-}$or Dock $8^{-/-}$TCR Tg mice. $\mathrm{Osmr}^{-/-}$mice were obtained from RIKEN BioResource Center (RBRC02711). Epas1 ${ }^{l o x} /$ lox mice were obtained from the Jackson Laboratory and crossed with CD4-Cre Tg mice to obtain CD4-Cre ${ }^{+}$Epas $1^{\text {lox } / \text { lox }}$ Dock8 ${ }^{-1-}$ AND Tg mice. CAG-OVA mice were purchased from the Jackson Laboratory. Mice were maintained under specific-pathogen-free conditions in the animal facility of Kyushu University, and age- and sex-matched littermates were used as controls. Animal experiments were approved by the committee of Ethics of Animal Experiments, Kyushu University. Mice were selected randomly and assigned to experimental groups according to genotype. The investigators who performed the experiments were not blinded to mouse genotypes.

Measurement of scratching behaviour. Mice were put into an acrylic cage $(11 \times 14 \times 20 \mathrm{~cm})$ for at least $1 \mathrm{~h}$ for acclimation, and their behaviours were videotaped. Playback of the video was used for determination of the total number of scratching bouts per $2 \mathrm{~h}$. When mice scratch, they stretch their hind paw toward the itchy spot, lean the head toward the hind paw, rapidly move the paw several times, and then lower it back to the floor. A series of these movements was counted as one bout of scratching, as previously described ${ }^{51}$.

Evaluation of skin disease. The severity of dermatitis was grossly assessed by the modified SCORAD method, as described previously ${ }^{31}$. This scoring is based on the severity of (1) erythema/hemorrhage, (2) scaling/dryness, (3) oedema and (4) excoriation/erosion. The degree of each symptom was scored as 0 (absence), 1 (mild), 2 (moderate) and 3 (severe). The sum of the individual scores (minimum 0 and maximum 12) was taken as the dermatitis score.

Histology and immunofluorescence. Skin tissues were fixed in $4 \%$ (w/v) paraformaldehyde and embedded in paraffin blocks. Sections $(3 \mu \mathrm{m}$ thick) were stained with haematoxylin and eosin, and examined by light microscopy. For immunofluorescence analyses, tissues were embedded in OCT compound (Sakura Finetech) and frozen in liquid nitrogen. Cryostat sections (10 $\mu \mathrm{m}$ thick) were fixed in $4 \%$ paraformaldehyde for $30 \mathrm{~min}$ and blocked with $10 \%$ goat serum for $1 \mathrm{~h}$ at room temperature. Sections were then stained with phycoerythrin (PE)-conjugated anti-mouse CD3 (17A2, $4 \mu \mathrm{g} \mathrm{ml}^{-1}$; Biolegend), fluorescein isothiocyanate (FITC)-conjugated anti-mouse CD45R/B220 (RA3-6B2, $5 \mu \mathrm{g} \mathrm{ml}^{-1}$; BD Biosciences), FITC-conjugated anti-mouse CD8a (53-6.7, $5 \mu \mathrm{g} \mathrm{ml}^{-1}$; BD Biosciences), and biotinylated anti-mouse CD4 (H129.19, $5 \mu \mathrm{g} \mathrm{ml}^{-1}$; BD Biosciences) antibodies followed by incubation with Alexa Fluor 488-conjugated streptavidin $\left(4 \mu \mathrm{g} \mathrm{ml}^{-1}\right.$; Thermo Fisher Scientific). For EPAS1 staining, MEFs $\left(3 \times 10^{5}\right.$ cells per $\left.\mathrm{ml}\right)$ were cultured on the poly-L-lysine coated glass-bottom dishes (Matsunami) in $1 \% \mathrm{O}_{2}$ for $30 \mathrm{~h}$, fixed with $4 \%(\mathrm{w} / \mathrm{v})$ paraformaldehyde for $30 \mathrm{~min}$ and permeabilized with $0.2 \%$ Triton X-100 for $30 \mathrm{~min}$. After being blocked with $10 \%$ goat serum for $1 \mathrm{~h}$ at room temperature, cells were then stained with 4',6-diamidino-2-phenylindole (DAPI; Dojindo Laboratories) and rabbit anti-EPAS1 antibody (\#100-122, $10 \mathrm{\mu g} \mathrm{ml}^{-1}$; NOVUS Biologicals), followed by incubation with Alexa Fluor 488-conjugated donkey anti-rabbit IgG Fab fragment (\#711-547-003, $3 \mu \mathrm{g} \mathrm{ml}^{-1}$; Jackson ImmunoReseach) antibody. All images were obtained with a laser scanning confocal microscope (Carl Zeiss).

ELISA. IL-31 concentrations in serum samples and cell culture supernatants were measured with ELISA kits (R\&D Systems for human samples and USCN for mouse samples), according to the manufacture's instructions. To measure the concentrations of serum IgE and IgG2b, serum samples were serially diluted and placed in 96-well plates coated with goat anti-mouse IgE (\#1110-01) or goat anti-mouse $\operatorname{Ig}\left(\operatorname{IgM}+\operatorname{IgG}+\operatorname{IgA}, \mathrm{H}+\mathrm{L}\right.$; \#1010-01) antibody (both $2.5 \mu \mathrm{g} \mathrm{ml}^{-1}$; Southern Biotech). After $2 \mathrm{~h}$ incubation, wells were washed with phosphatebuffered saline (PBS) and incubated with alkaline phosphatase-conjugated rat anti-mouse IgE (\#1130-04, 1:3,000 dilution; Southern Biotech) or goat anti-mouse IgG2b (\#1090-04, 1:100,000 dilution; Southern Biotech) antibody.

Flow cytometry. The following antibodies and reagents were used. FITC-conjugated anti-mouse CD45R/B220 (RA3-6B2, $5 \mu \mathrm{g} \mathrm{ml}^{-1}$ ), FITC-conjugated anti-mouse CD4 (RM4-5, $\left.5 \mu \mathrm{g} \mathrm{ml}^{-1}\right)$, biotinylated anti-mouse CD4 (RM4-5, $2.5 \mu \mathrm{g} \mathrm{ml}^{-1}$ ), PE-conjugated anti-mouse CD8a (53-6.7, $1 \mu \mathrm{g} \mathrm{ml}^{-1}$ ), PE-conjugated anti-mouse CD44 (IM7, $1 \mu \mathrm{g} \mathrm{ml}^{-1}$ ), FITC-conjugated anti-mouse CD62L (MEL-14, $5 \mu \mathrm{g} \mathrm{ml}^{-1}$ ), FITC-conjugated anti-mouse $\mathrm{V} \alpha 11$
(RR8-1, $5 \mu \mathrm{g} \mathrm{ml}^{-1}$ ), FITC-conjugated anti-mouse V $\alpha 2\left(\mathrm{~B} 20.1,5 \mu \mathrm{g} \mathrm{ml}^{-1}\right.$ ), biotinylated anti-mouse V $\beta 3\left(\mathrm{KJ} 25,2.5 \mu \mathrm{g} \mathrm{ml}^{-1}\right)$, biotinylated anti-mouse V 35 (MR9-4, $2.5 \mu \mathrm{g} \mathrm{ml}^{-1}$ ), and allophycocyanin (APC)-conjugated streptavidin $\left(0.1 \mu \mathrm{g} \mathrm{ml}^{-1}\right)$ or PerCP-5.5cyanine-conjugated streptavidin $\left(0.5 \mu \mathrm{g} \mathrm{ml}^{-1}\right)$ were from BD Biosciences. Biotinylated anti-mouse CD90.2/Thy1.2 (30-H12, $0.25 \mu \mathrm{g} \mathrm{ml}^{-1}$ ) was purchased from eBioscience. Before staining with the antibodies, cells were incubated for $10 \mathrm{~min}$ on ice with anti-Fc $\gamma$ III/II receptor (2.4G2, $0.5 \mu \mathrm{g} \mathrm{ml}^{-1}$; BD Biosciences) antibody to block $\mathrm{Fc}$ receptors. Flow cytometoric analyses were done on FACS Calibur (BD Biosciences).

Activation and transfer of mouse CD4 ${ }^{+} \mathbf{T}$ cells. Mouse $\mathrm{CD} 4^{+} \mathrm{T}$ cells were isolated from the spleen and peripheral lymph nodes (PLNs) by magnetic sorting with Dynabeads mouse CD4 followed by treatment with DETACHaBEAD mouse CD4 (Life Technologies), and suspended in RPMI 1640 medium (Wako) containing $10 \%$ heat-inactivated fetal calf serum (FCS; Nichirei Bioscience), $50 \mu \mathrm{M}$ 2-mercaptoethanol (Nacalai tesque), $2 \mathrm{mM}$ L-glutamine (Life Technologies), $100 \mathrm{U} \mathrm{ml}^{-1}$ penicillin (Life Technologies), $100 \mu \mathrm{g} \mathrm{ml}^{-1}$ streptomycin (Life Technologies), $1 \mathrm{mM}$ sodium pyruvate (Life Technologies) and MEM non-essential amino acids (Life Technologies). For primary stimulation, CD4 ${ }^{+}$ $\mathrm{T}$ cells $\left(3 \times 10^{5}\right.$ cells per well) were cultured in a 24 -well plate with T cell-depleted, irradiated spleen cells $\left(5 \times 10^{6}\right.$ cells per well) in the presence of the following peptides: MCC88-103 (ANERADLIAYLKQATK, $3 \mu \mathrm{g} \mathrm{ml}{ }^{-1}$ ) or OVA323-339 (ISQAVHAAHAEINEAGR, $1 \mu \mathrm{g} \mathrm{ml}^{-1}$ ). In some experiments, activated $\mathrm{CD} 4{ }^{+} \mathrm{T}$ cells $\left(5.7 \times 10^{6}\right.$ per mouse) from Dock $8^{+1-}$ and Dock $8^{-1-}$ OTII Tg mice were intravenously injected into CAG-OVA mice $5 \mathrm{~h}$ before assays. For secondary stimulation, $\mathrm{CD} 4{ }^{+} \mathrm{T}$ cells recovered from the culture were re-stimulated with plate-bound anti-CD3e antibody $\left(145-2 \mathrm{C} 11,1 \mu \mathrm{g} \mathrm{ml}^{-1}\right.$; eBioscience) and anti-CD28 antibody (37.51, $1 \mu \mathrm{g} \mathrm{ml}^{-1}$; BD Biosciences) for specified times. T cell proliferation assays were done by cultivating $\mathrm{CD} 4{ }^{+} \mathrm{T}$ cells $\left(5 \times 10^{4}\right.$ per well $)$ with T cell-depleted, irradiated spleen cells $\left(1 \times 10^{6}\right.$ cells per well) in the presence or absence of various concentrations of the relevant peptide for $66 \mathrm{~h} .\left[{ }^{3} \mathrm{H}\right]$-thymidine $(0.037 \mathrm{MBq})$ was added during the final $18 \mathrm{~h}$ of the culture, and the incorporated radioactivity was measured with a liquid scintillation counter.

Preparation of MEFs. Primary MEFs were generated from WT, Dock $8^{-/-}$mice and Epas ${ }^{l o x} / l o x$ mice at E13.5, and Epas1 gene expression was deleted in Epas ${ }^{\text {lox/lox }}$ MEFs by expressing pIC-Cre encoding Cre recombinase (provided by K. Takeda, Osaka University, Osaka, Japan). These MEFs were immortalized by transfection with a plasmid pCX4bsr-SV40ER (provided by T. Akagi, KAN Research Institute, Kobe, Japan) before use. Immortalized MEFs were cultured in DMEM medium (Wako Pure Chemical Industries) supplemented with $10 \%$ heat-inactivated FCS (Nichirei Bioscience), $100 \mathrm{U} \mathrm{ml}^{-1}$ penicillin (Life Technologies) and $100 \mu \mathrm{g} \mathrm{ml}^{-1}$ streptomycin (Life Technologies).

Preparation and activation of human $\mathbf{C D}^{+}{ }^{+} \mathbf{T}$ cells. Human peripheral blood mononuclear cells (PBMCs) were separated by Percoll (GE Healthcare) gradient centrifugation, and $\mathrm{CD} 44^{+} \mathrm{T}$ cells were isolated from PBMCs by magnetic sorting with Dynabeads human CD4 followed by treatment with DETACHaBEAD human CD4 (Life Technologies). After being suspended in complete RPMI 1640 medium, $\mathrm{CD} 4{ }^{+} \mathrm{T}$ cells $\left(3 \times 10^{5}\right.$ cells per well) were stimulated in a 24 -well plate coated with anti-human CD3 $\varepsilon$ antibody (Hit3a, $10 \mu \mathrm{g} \mathrm{ml}^{-1}$; Tonbo Biosciences) for 3 or $6 \mathrm{~h}$. In some experiments, $\mathrm{CD} 4^{+} \mathrm{T}$ cells were treated with EPAS1 inhibitors, FM 19G11 or HIFVII at $30 \mu \mathrm{M}$ (both from Calbiochem). Human peripheral blood samples were obtained from a DOCK8-deficient patien ${ }^{34}, \mathrm{AD}$ patients and healthy volunteers in compliance with Institutional Review Board protocols. AD was diagnosed according to the criteria provided by the Japanese Dermatological Association $^{52}$. The details for the AD patients and healthy controls are shown in Supplementary Table 2 . The experiments were approved by the Ethics committee of Kyushu University Hospital and Fujita Health University, and a written informed consent was obtained from all patients.

Reverse transcription-PCR. Total RNA was isolated using ISOGEN (Nippon Gene). After treatment with RNase-free DNase I (Life Technologies), RNA samples were reverse-transcribed with oligo(dT) primers (Life Technologies) and SuperScript III reverse transcriptase (Life Technologies) for amplification by PCR. The primers used for conventional reverse transcription-PCR and real-time PCR are listed in Supplementary Table 3. Real-time PCR was performed on an ABI PRISM 7,000 Sequence Detection System using the SYBR Green PCR Master Mix (both from Applied Biosystems). The expressions of human and mouse target genes were normalized to expression of GAPDH and Hprt, respectively. Sequencedetection software supplied with the instrument was used for analyses.

Microarray analysis. Total RNA was isolated using ISOGEN (Nippon Gene), and cRNA was amplified and labelled using a Low Input Quick Amp Labeling Kit (Agilent Technologies). The cRNA was then hybridized to a $44 \mathrm{~K}$ 60-mer oligomicroarray (Whole Mouse Genome oligo DNA Microarray Kit Ver 2.0; Agilent Technologies). The hybridized microarray slides were scanned using an 
Agilent scanner. The relative hybridization intensities and background hybridization values were calculated using Feature Extraction Software version 9.5.1.1 (Agilent Technologies). Raw signal intensities and flags for each probe were calculated from the hybridization intensities and spot information, according to the procedures recommended by Agilent Technologies. To identify up- or downregulated genes in experimental samples, we calculated $Z$-scores and ratios from the normalized signal intensities of each probe (upregulated genes, $Z$-score $>2.0$ and ratio $>1.5$-fold; down-regulated genes, $Z$-score $<-2.0$ and ratio $<0.66$-fold).

Knock down of target genes by siRNAs. To knock down Epas1 or Mst1 gene expression in Dock $8^{-/-}$or Dock8 ${ }^{+/-}$AND CD4 ${ }^{+} \mathrm{T}$ cells, the Accell siRNA SMART pool, E-040635-00-0005 or E-059385-00-0005 (both from Dharmacon) was used, respectively. Transfection was performed according to the manufacturer's instructions using the irrelevant oligonucleotide (Accell Red Non-targeting siRNA; D-001960-01-05, Dharmacon) as a control. Briefly, Dock $8^{-9-}$ or Dock8 ${ }^{+/-}$AND CD4 ${ }^{+} \mathrm{T}$ cells $\left(3 \times 10^{5}\right.$ cells per well $)$ were cultured with T cell-depleted, irradiated spleen cells $\left(5 \times 10^{6}\right.$ cells per well $)$ and MCC88-103 peptide $\left(3 \mu \mathrm{g} \mathrm{ml}^{-1}\right)$ in Accell siRNA Delivery Media (Dharmacon) supplemented with $2.5 \%$ FCS. The siRNA or the irrelevant oligonucleotide was added to the culture at the final concentration of $1 \mu \mathrm{M}$. After 4 days of the culture, viable $\mathrm{CD} 4{ }^{+} \mathrm{T}$ cells were recovered and re-stimulated with plate-bound anti-CD3e $\left(145-2 \mathrm{C} 11,1 \mu \mathrm{g} \mathrm{ml}^{-1}\right)$ and anti-CD28 (37.51, $\left.1 \mu \mathrm{g} \mathrm{ml}^{-1}\right)$ antibodies for $3 \mathrm{~h}$.

Knock down of EPAS1 or DOCK8 gene expression in human $\mathrm{CD} 4^{+} \mathrm{T}$ cells was performed with the Accell siRNA SMART pool, E-004814-00-0005 or E-02610600-0005 (both from Dharmacon) with irrelevant oligonucleotide (Accell Red Non-targeting siRNA; D-001960-01-05, Dharmacon) as a control. For this purpose, human PBMCs $\left(1 \times 10^{6}\right.$ cells per well) were cultured with staphylococcal enterotoxin B $\left(0.1 \mu \mathrm{g} \mathrm{ml}^{-1}\right.$; Sigma-Aldrich) in Accell siRNA Delivery Media (Dharmacon) supplemented with $2.5 \%$ FCS. The siRNA or control oligonucleotide was added to the culture at the final concentration of $1 \mu \mathrm{M}$. After 4 days (for EPAS1 knock-down) or 2 days (DOCK8 knock-down) of the culture, viable CD4 ${ }^{+} \mathrm{T}$ cells were recovered by magnetic sorting and re-stimulated with plate-bound anti-CD3 $\varepsilon$ (Hit3a, $10 \mu \mathrm{g} \mathrm{ml}^{-1}$ ) antibody for $3 \mathrm{~h}$. In these experiments, knock down efficacy was checked by reverse transcription-PCR.

To knock down Sp1 and Arnt gene expression in MEFs, the siRNAs (On-Target plus SMART pool, L-040633-02-0005 and L-040639-01-0005) were obtained from Dharmacon, and the irrelevant oligonucleotide (BLOCK-iT Alexa Fluor Red; Life Technologies) was used as a negative control. For transfection, $400 \mu \mathrm{l}$ of the siRNA solution $(150 \mathrm{nM}$ ) in serum-free DMEM medium (Wako) was mixed with $5 \mu \mathrm{l}$ DharmaFect transfection reagent for $20 \mathrm{~min}$ at room temperature. This mixture $(400 \mu \mathrm{l})$ was added drop-wise to MEFs $\left(3 \times 10^{5}\right.$ cells per well) suspended in $1.6 \mathrm{ml}$ DMEM medium containing $10 \%$ FCS. Then, cells were incubated for $24 \mathrm{~h}$ at $37^{\circ} \mathrm{C}$ before transient transfection for luciferase reporter assays. Knock down efficacy was checked by Western blot analyses.

Plasmids and transfection. To generate the Il31 reporter plasmid (pGL4.10-Il31), the promoter region of the mouse Il31 gene from position $-1,367$ to -1 was amplified by PCR and subcloned into pGL4.10[luc2] vector (Promega). Deletions and mutations in the Il31 promoter region were created by PCR. These plasmids were transfected into MEFs with Lipofectamine 2,000 reagent (Life Technologies) for luciferase reporter assays. The pcDNA vector (Invitrogen) was used to create expression vectors encoding FLAG-tagged human and mouse EPAS1 (pcDNA-EPAS1) or its deletion mutants, HA-tagged mouse DOCK8 (pcDNA-DOCK8) or its mutant, FLAG- or V5-tagged mouse MST1 (pcDNA-MST1), V5-tagged mouse SP1 (pcDNA-SP1) and HA-tagged human and mouse ARANT (pcDNA-ARNT). These expression constructs were transfected into HEK-293T cells with polyethyleminine for immunoprecipitation. The $\mathrm{pB}$ vector encoding neomycin (pBJ-neo) was used to express HA-tagged WT mouse DOCK8 and its mutants, $\Delta \mathrm{N}$ lacking the $\mathrm{N}$-terminal 527 amino acid residues and $\triangle$ DHR2 lacking amino acid residues from 1,535 to 2,100 . The retroviral vector pMX was used to generate the plasmid encoding pMX-Epas1-IRES-GFP. This plasmid DNA was transfected into Platinum-E packaging cells with FuGENE 6 transfection reagent (Promega). The cell culture supernatants were harvested $48 \mathrm{~h}$ after transfection, supplemented with polybrene $\left(5 \mathrm{\mu g} \mathrm{ml}^{-1}\right)$ and IL-2 $\left(5 \mathrm{ng} \mathrm{ml}^{-1}\right)$, and were used to infect $\mathrm{CD} 4{ }^{+} \mathrm{T}$ cells stimulated with plate-bound anti-CD3 $\varepsilon$ and anti-CD28 antibodies. After centrifugation at $700 \mathrm{~g}$ for $1 \mathrm{~h}$, plates were incubated for $8 \mathrm{~h}$ at $32^{\circ} \mathrm{C}$ and for $16 \mathrm{~h}$ at $37^{\circ} \mathrm{C}$. Two additional retroviral infections were performed at daily intervals, and the GFP-positive $\mathrm{CD} 4{ }^{+} \mathrm{T}$ cells were sorted by FACSAria (BD Biosciences) for RNA extraction $30 \mathrm{~h}$ after the third transfection. To generate the retroviral vector pSUPER retro-puro sh Mst1, the following oligonucleotides corresponding to specific regions of Mst 1 gene were ligated to the pSUPER retro-puro vector (OligoEngine) at the Bgl II and Hind III sites: $5^{\prime}$-GATCTCACCGCCAGATTGTTGCAATCAAGCCGAAGCTTGATTGCAACAATC TGGCTTTTA- $3^{\prime}$ and $5^{\prime}$-AGCTTAAAAGCCAGATTGTTGCA ATCAAGCTTCGGCTT GATTGCAACAATCTGGCGGTGA-3'. MEFs were retrovirally transduced with pSUPER retro-puro sh $M s t 1$ as described above.

Luciferase reporter assays. MEFs were co-transfected with pRL-SV40-Renilla luciferase plasmid $(0.1 \mu \mathrm{g}$; Promega) and pGL4.10-Il31 $(2 \mu \mathrm{g})$ in the presence of
pcDNA-Epas1 or its mutants $(2 \mu \mathrm{g})$. For transfection, these plasmid DNAs were mixed with Lipofectamine 2,000 transfection reagent $(5 \mu \mathrm{l})$ in the Opti-MEM medium ( $500 \mu$ l; Life Technologies) for $20 \mathrm{~min}$ at room temperature, and the mixture was added drop-wise to MEFs $\left(3 \times 10^{5}\right.$ cells per well) cultured in $1.5 \mathrm{ml}$ of DMEM medium containing $1 \%$ FCS. $6 \mathrm{~h}$ after transfection, cells were suspended in DMEM containing $10 \%$ FCS and incubated for additional $24 \mathrm{~h}$. In some experiments, pGL4.10-Il31-derived mutants were used. The total amount of plasmid DNA was equalized by the control vector. Luciferase activity was measured with a Dual-Luciferase Reporter Assay System according to the manufacture's protocols (Promega)

Immunoblotting and immunoprecipitation. Cells were lysed on ice in $20 \mathrm{mM}$ Tris-HCl buffer (pH 7.5) containing $1 \%$ Triton X-100, $150 \mathrm{mM} \mathrm{NaCl}, 1 \mathrm{mM}$ EDTA, $1 \mathrm{mM}$ EGTA, $2.5 \mathrm{mM}$ sodium pyrophosphate, $1 \mathrm{mM} \beta$-glycerophosphate, $1 \mathrm{mM} \mathrm{Na} \mathrm{VO}_{4}$, and complete protease inhibitors (Roche). After centrifugation, the supernatants were mixed with an equal volume of $2 \times$ sample buffer (125 mM Tris- $\mathrm{HCl}, 0.01 \%$ bromophenol blue, $4 \%$ SDS, $20 \%$ glycerol and $200 \mu \mathrm{M}$ dithiothreitol). Samples were boiled for $5 \mathrm{~min}$ and analysed by immunoblotting. The following antibodies were used: rabbit anti-EPAS1 (\#100-122, 1:1,000 dilution Novus Biologicals), rabbit anti-SP1 (\#07-645, 1:1,000 dilution; Millipore), rabbit anti-ARNT (\#5537, 1:1,000 dilution; Cell Signaling), rabbit anti-MST1 (\#3682, 1:1,000 dilution; Cell Signaling), goat anti- $\beta$ actin (I-19, 1:1,000 dilution; Santa Cruz), rat anti-HA (3F10, 1:2,000 dilution; Roche), anti-FLAG (\#PM020-7, 1:4,000 dilution; MBL) and anti-V5 (R961-25, 1:2,000 dilution; Life Technologies). Polyclonal antibody against DOCK8 was produced by immunizing rabbits with KLH-coupled synthetic peptide corresponding to the C-terminal sequence of human and mouse DOCK8 (RDSFHRSSFRKCETQLSQGS, $3.8 \mu \mathrm{g} \mathrm{ml}^{-1}$ ). To examine association between DOCK8 and MST1 in activated $\mathrm{CD} 4{ }^{+} \mathrm{T}$ cells, cell extracts were immunoprecipitated with anti-DOCK8 antibody or control rabbit IgG (\#011-000-002, Jackson ImmunoReseach). The bound proteins were analysed by SDS-PAGE, and blots were probed with rabbit anti-MST1 antibody (\#3682, 1:1,000 dilution; Cell Signaling) followed by mouse anti-rabbit IgG light-chain specific antibody (L57A3, 1:1,000 dilution; Cell Signaling) and horseradish peroxidase (HRP)-conjugated goat anti-mouse IgG (\#2005, 1:2000 dilution; Santa Cruz). In some experiments, HEK-293T cells transfected with the specified plasmid DNAs were subjected to immunoprecipitation using the relevant antibodies.

EMSA. Nuclear extracts were prepared from MEFs using the standard method. Briefly, cells were rinsed with PBS, resuspended in buffer A (10 mM HEPES- $\mathrm{K}^{+}$ pH 7.9, $10 \mathrm{mM} \mathrm{KCl}, 0.1 \mathrm{mM}$ EDTA, $0.1 \mathrm{mM}$ EGTA, $0.5 \mathrm{mM}$ DTT, $1 \mathrm{mM}$ PMSF) and incubated on ice for $15 \mathrm{~min}$. Cells were then lysed by adding NP-40 to a final concentration of $0.67 \%$ and immediately vortexing for $10 \mathrm{~s}$. The lysate was centrifuged at $20,000 \mathrm{~g}$ for $30 \mathrm{~s}$ at $4{ }^{\circ} \mathrm{C}$ to pellet nuclei. Nuclei were resuspended in buffer B (20 mM HEPES-K ${ }^{+}$, pH 7.9, $400 \mathrm{mM} \mathrm{NaCl}, 1 \mathrm{mM}$ EDTA, 1 mM EGTA, $1 \mathrm{mM}$ DTT, $1 \mathrm{mM}$ PMSF), incubated for $15 \mathrm{~min}$ on ice with intermittent agitation and centrifuged at $20,000 \mathrm{~g}$ for $5 \mathrm{~min}$ at $4^{\circ} \mathrm{C}$ to obtain nuclear extracts. A DNA probe corresponding to the mouse Il31 promoter region containing the consensus SP1-binding sequence (WT; $5^{\prime}$ - TGCCATGGGCGGGCCTTTGATCTGCTTC- $3^{\prime}$ ) was labelled with $\gamma^{-32}$ P-ATP (Perkin Elmer) using T4 polynucleotide kinase (Promega) and purified using illustra ${ }^{\mathrm{TM}}$ MicroSpin $^{\mathrm{TM}}$ G-25 columns (GE Healthcare). For protein-DNA binding, $4 \mu \mathrm{g}$ nuclear extracts were incubated in $9 \mu \mathrm{l}$ of binding buffer (20 mM HEPES- $\mathrm{K}^{+}$, pH $7.9,50 \mathrm{mM} \mathrm{KCl}, 3 \mathrm{mM} \mathrm{MgCl}, 10 \%$ glycerol, $1 \mathrm{mM}$ DTT) supplemented with $2 \mu \mathrm{g}$ poly(dI-dC) (Sigma-Aldrich) with or without unlabelled competitor DNA (WT or its mutant; 5' - TGCCATGGGCGAAGTTTTG ATCTGCTTC-3'; $1.75 \mathrm{pmol}$ ) for $2.5 \mathrm{~h}$ on ice, before addition of $1 \mu \mathrm{l}$ of ${ }^{32} \mathrm{P}$-labelled probe $(0.035 \mathrm{pmol})$ and incubation at room temperature for 20 min. Protein-DNA complexes were separated on a $6 \%$ native polyacrylamide/ $0.5 \times \mathrm{TBE}$ gel at $4{ }^{\circ} \mathrm{C}$, dried onto a filter paper at $80^{\circ} \mathrm{C}$ for $2 \mathrm{~h}$ under vacuum and analysed with the BAS2,000 BIO Imaging Analyzer (Fuji Photo Film). For supershift assays, $3 \mu \mathrm{g}$ anti-SP1 antibody (\#07-645; Millipore) or $6 \mu \mathrm{g}$ anti-GFP antibody (A11122; Invitrogen) as a control were added to nuclear extracts and incubated on ice for $2.5 \mathrm{~h}$ before addition of radiolabelled probes.

ChIP assay. CD4 ${ }^{+}$T cells were prepared from CD4-Cre ${ }^{+}$or CD4-Cre ${ }^{-}$
Epas lox/lox Dock8 ${ }^{-/-}$AND Tg mice and were stimulated with MCC88-103. After re-stimulation with plate-bound anti-CD3 $\varepsilon$ and anti-CD28 antibodies, cells were cross-linked with $1 \%$ formaldehyde for $10 \mathrm{~min}$ at room temperature and then neutralized with glycine for $5 \mathrm{~min}$ at room temperature. Cells were washed twice with PBS containing protease inhibitors, and then nuclei were isolated using the Magna ChIP ${ }^{\mathrm{TM}}$ HiSens kit (Millipore) according to the manufacturer's protocol. Isolated nuclei were resuspended in sonication buffer and sonicated using the Branson sonifier (Cell disruptor 200) with 16 sets of 10 pulses using the power set at 5.5 on ice for shearing chromatin DNA. After centrifugation at $10,000 \mathrm{~g}$ for 10 min at $4{ }^{\circ} \mathrm{C}$, sheared chromatin DNA was obtained and treated with RNase and proteinase K for quantifying DNA content. For immunoprecipitation, 3.5-5 $\mu \mathrm{g}$ chromatin DNA was mixed with magnetic Protein A/G beads preincubated with $2 \mu \mathrm{g}$ anti-SP1 antibody (\#07-645; Millipore) or $1 \mu \mathrm{g}$ rabbit normal IgG (\#2729; Cell Signaling) and incubated at $4{ }^{\circ} \mathrm{C}$ overnight. The magnetic beads were 
washed three times with buffer containing physiologic salt and once with low salt buffer. Then, the magnetic beads were treated with proteinase $\mathrm{K}$ at $65^{\circ} \mathrm{C}$ for $2 \mathrm{~h}$, and heated at $95^{\circ} \mathrm{C}$ for $15 \mathrm{~min}$ for inactivation of proteinase $\mathrm{K}$ and elution of bound chromatin DNA. Eluted DNA and input chromatin DNA were analysed with a CFX Connect real-time PCR detection system (BioRad) using the KOD SYBR qPCR mix (TOYOBO) and the following primers: mouse Il31 promoter $(-249 /-97) 5^{\prime}$-ATCTTCTGCCTTGCCTTGAG- $3^{\prime}$ and $5^{\prime}$-ATGAGGAAGCAGATCAAAGG- ${ }^{\prime}$. Data were normalized for the amount of the input chromatin DNA.

Statistical analysis. Sample sizes for each experiment were determined on the variability observed in preliminary experiments and prior experience with the experimental systems. Statistical analyses were performed using GraphPad Prism. We first calculated the Gaussian distribution of the data using the KolmogorovSmirnov test. When two groups were compared, two-tailed Student's $t$-test (Gaussian distribution) or Mann-Whitney test (no Gaussian distribution) was used. When several groups were compared, we used a one-way analysis of variance (multiple groups) followed by post hoc Bonferroni test. $P$ values less than 0.05 were considered significant.

Data availability. Microarray data that support the findings of this study have been deposited in Gene Expression Omnibus with the primary accession code GSE75686. The authors declare that all other data supporting the findings of this study are available within the article and its Supplementary Information Files.

\section{References}

1. Zhang, Q. et al. Combined immunodeficiency associated with DOCK8 mutations. N. Engl. J. Med. 361, 2046-2055 (2009).

2. Engelhardt, K. R. et al. The extended clinical phenotype of 64 patients with dedicator of cytokinesis 8 deficiency. J. Allergy Clin. Immunol. 136, 402-412 (2015).

3. Zhang, Q., Davis, J. C., Dove, C. G. \& Su, H. C. Genetic, clinical, and laboratory markers for DOCK8 immunodeficiency syndrome. Dis. Markers 29, 131-139 (2010).

4. Freeman, A. F. \& Holland, S. M. Clinical manifestations of hyper IgE syndromes. Dis. Markers 29, 123-130 (2010).

5. Yong, P. F. et al. An update on the hyper-IgE syndromes. Arthritis Res. Ther. 14, 228 (2012).

6. Harada, Y. et al. DOCK8 is a Cdc42 activator critical for interstitial dendritic cell migration during immune responses. Blood 119, 4451-4461 (2012).

7. Jabara, H. H. et al. DOCK8 functions as an adaptor that links TLR-MyD88 signaling to B cell activation. Nat. Immunol. 13, 612-620 (2012)

8. Mizesko, M. C. et al. Defective actin accumulation impairs human natural killer cell function in patients with dedicator of cytokinesis 8 deficiency. J. Allergy Clin. Immunol. 131, 840-848 (2013).

9. Zhang, Q. et al. DOCK8 regulates lymphocyte shape integrity for skin antiviral immunity. J. Exp. Med. 211, 2549-2566 (2014).

10. Randall, K. L. et al. Dock8 mutations cripple B cell immunological synapses, germinal centers and long-lives antibody production. Nat. Immunol. 10, 1283-1291 (2009).

11. Lambe, T. et al. DOCK8 is essential for T-cell survival and the maintenance of CD8 ${ }^{+}$T-cell memory. Eur. J. Immunol. 41, 3423-3435 (2011).

12. Randall, K. L. et al. DOCK8 deficiency impairs CD8 T cell survival and function in humans and mice. J. Exp. Med. 208, 2305-2320 (2011).

13. Crawford, G. et al. DOCK8 is critical for the survival and function of NKT cells. Blood 122, 2052-2061 (2013).

14. Singh, A. K., Eken, A., Fry, M., Bettelli, E. \& Oukka, M. DOCK8 regulates protective immunity by controlling the function and survival of ROR $\gamma+$ ILCs. Nat. Commun. 5, 4603 (2014).

15. Krishnaswamy, J. K. et al. Coincidental loss of DOCK8 function in NLRP10deficient and $\mathrm{C} 3 \mathrm{H} / \mathrm{HeJ}$ mice results in defective dendritic cell migration. Proc. Natl Acad. Sci. USA 112, 3056-3061 (2015).

16. Dillon, S. R. et al. Interleukin 31, a cytokine produced by activated T cells, induces dermatitis in mice. Nat. Immunol. 5, 752-760 (2004).

17. Cornelissen, C., Lüscher-Firzlaff, J., Baron, J. M. \& Lüscher, B. Signaling by IL-31 and functional consequences. Eur. J. Cell Biol. 91, 552-566 (2012).

18. Sonkoly, E. et al. IL-31: a new link between T cells and pruritus in atopic skin inflammation. J. Allergy Clin. Immunol. 117, 411-417 (2006).

19. Cevikbas, F. et al. A sensory neuron-expressed IL-31 receptor mediates Thelper cell-dependent itch: involvement of TRPV1 and TRPA1. J. Allergy Clin. Immunol. 133, 448-460 (2014).

20. Bilsborough, J. et al. IL-31 is associated with cutaneous lymphocyte antigenpositive skin homing $\mathrm{T}$ cells in patients with atopic dermatitis. J. Allergy Clin. Immunol. 117, 418-425 (2006).
21. Raap, U. et al. Correlation of IL-31 serum levels with severity of atopic dermatitis. J. Allergy Clin. Immunol. 122, 421-423 (2008).

22. Nemoto, O. et al. The first trial of CIM331, a humanized anti-human IL-31 receptor A antibody, for healthy volunteers and patients with atopic dermatitis to evaluate safety, tolerability and pharmacokinetics of a single dose in a randomised, double-blind, placebo-controlled study. Br. J. Dermatol. 174, 296-304 (2016).

23. Tian, H., McKnight, S. L. \& Russell, D. W. Endothelial PAS domain protein 1 (EPAS1), a transcription factor selectively expressed in endothelial cells. Genes Dev. 11, 72-82 (1997).

24. Keith, B., Johnson, R. S. \& Simon, M. C. HIF1 $\alpha$ and HIF2 $\beta$ : sibling rivalry in hypoxic tumour growth and progression. Nat. Rev. Cancer 12, 9-22 (2012).

25. Semenza, G. L. Hypoxia-inducible factors in physiology and medicine. Cell 148, 399-408 (2012).

26. Wu, D., Potluri, N., Lu, J., Kim, Y. \& Rastinejad, F. Structural integration in hypoxia-inducible factors. Nature 524, 303-308 (2015).

27. Elo, L. L. et al. Genome-wide profiling of interleukin-4 and STAT6 transcription factor regulation of human Th2 cell programming. Immunity 32, 852-862 (2010).

28. O’shea, J. J., Lahesmaa, R., Vahedi, G., Laurence, A. \& Kanno, Y. Genomic views of STAT function in $\mathrm{CD} 4^{+} \mathrm{T}$ helper cell differentiation. Nat. Rev. Immunol. 11, 239-250 (2011).

29. Kaye, J., Vasquez, N. J. \& Hedrick, S. M. Involvement of the same region of the $\mathrm{T}$ cell antigen receptor in thymic selection and foreign peptide recognition. J. Immunol. 148, 3342-3353 (1992).

30. Kunz, B. et al. Clinical validation and guidelines for the SCORAD index: consensus report of the European Task Force on Atopic Dermatitis. Dermatology 195, 10-19 (1997).

31. Choi, Y. J. et al. Therapeutic effects and immunomodulation of suanbo mineral water therapy in a murine model of atopic dermatitis. Ann. Dermatol. 25, 462-470 (2013).

32. Tanaka, M. et al. Targeted disruption of oncostatin $\mathrm{M}$ receptor results in altered hematopoiesis. Blood 102, 3154-3162 (2003).

33. Rawat, S. J. \& Chernoff, J. Regulation of mammalian Ste20 (Mst) kinases. Trends Biochem. Sci. 40, 149-156 (2015).

34. Tsuge, I. et al. Acute eosinophilic pneumonia occurring in a dedicator of cytokinesis 8 (DOCK8) deficient patient. Pediatr. Pulmonol. 49, E52-E55 (2014).

35. Moreno-Manzano, V. et al. FM19G11, a new hypoxia-inducible factor (HIF) modulator, affects stem cell differentiation status. J. Biol. Chem. 285, 1333-1342 (2010).

36. Scheuermann, T. H. et al. Allosteric inhibition of hypoxia inducible factor-2 with small molecules. Nat. Chem. Biol. 9, 271-276 (2013).

37. Tian, H., Hammer, R. E., Matsumoto, A. M., Russell, D. W. \& McKnight, S. L. The hypoxia-responsive transcription factor EPAS1 is essential for catecholamine homeostasis and protection against heart failure during embryonic development. Genes Dev. 12, 3320-3324 (1998).

38. Peng, J., Zhang, L., Drysdale, L. \& Fong, G. H. The transcription factor EPAS-1 /hypoxia-inducible factor $2 \alpha$ plays an important role in vascular remodeling. Proc. Natl Acad. Sci. USA 97, 8386-8391 (2000).

39. Compernolle, V. et al. Loss of HIF- $2 \alpha$ and inhibition of VEGF impair fetal lung maturation, whereas treatment with VGEF prevents fatal respiratory distress in premature mice. Nat. Med. 8, 702-710 (2002).

40. Scortegagna, M. et al. Multiple organ pathology, metabolic abnormalities and impaired homeostasis of reactive oxygen species in Epas $1^{-1-}$ mice. Nat. Genet. 35, 331-340 (2003).

41. Saito, T. et al. Transcriptional regulation of endochondral ossification by HIF$2 \alpha$ during skeletal growth and osteoarthritis development. Nat. Med. 16, 678-686 (2010).

42. Yang, S. et al. Hypoxia-inducible factor-2 $\alpha$ is a catabolic regulator of osteoarthritic cartilage destruction. Nat. Med. 16, 687-693 (2010).

43. Koizume, S. et al. HIF2 $\alpha$-Sp1 interaction mediates a deacetylation-dependent FVII-gene activation under hypoxic conditions in ovarian cancer cells. Nucleic Acids Res. 40, 5389-5401 (2012).

44. Xie, L. \& Collins, J. F. Transcription factors Sp1 and Hif2 $\alpha$ mediate induction of the copper-transporting ATPase $(A t p 7 a)$ gene in intestinal epithelial cells during hypoxia. J. Biol. Chem. 288, 23943-23952 (2013).

45. Pawlus, M. R. \& Hu, C. J. Enhanceosomes as integrators of hypoxia inducible factor (HIF) and other transcription factors in the hypoxic transcriptional response. Cell Signal. 25, 1895-1903 (2013).

46. Halacli, S. O. et al. STK4 (MST1) deficiency in two siblings with autoimmune cytopenias: a novel mutation. Clin. Immunol. 161, 316-323 (2015).

47. Nehme, N. T. et al. MST1 mutations in autosomal recessive primary immunodeficiency characterized by defective naive T-cell survival. Blood 119, 3458-3468 (2012). 
48. Dang, T. S. et al. Defective leukocyte adhesion and chemotaxis contributes to combined immunodeficiency in humans with autosomal recessive MST1 deficiency. J. Clin. Immunol. 36, 117-122 (2016).

49. Mandl, J. N., Monteiro, J. P., Vrisekoop, N. \& Germain, R. N. T cell-positive selection uses self-ligand binding strength to optimize repertoire recognition of foreign antigens. Immunity 38, 263-274 (2013).

50. Bieber, T. Atopic dermatitis. N. Engl. J. Med. 358, 1483-1494 (2008).

51. Andoh, T. \& Kuraishi, Y. Antipruritic mechanisms of topical E6005, a phosphodiesterase 4 inhibitor: inhibition of responses to proteinase- activated receptor 2 stimulation mediated by increase in intracellular cyclic AMP. J. Dermatol. Sci. 76, 206-213 (2014).

52. Saeki, H. et al. Guidelines for management of atopic dermatitis. J. Dermatol. 36, 563-577 (2009).

\section{Acknowledgements}

We thank T. Saito for AND TCR Tg mice; S. Yamasaki for Tg mice expressing Cre-recombinase under CD4 enhancer/promoter (CD4-Cre Tg mice); A. Miyajima and $\mathrm{K}$. Nakamura for their kind permission to use Osmr-/- mice in this study; and K. Takeda and T. Akagi for plasmid vectors. We also thank A. Inayoshi, Siqinbala and A. Aosaka for technical assistance. This research is supported by the Leading Advanced Projects for Medical Innovation (LEAP; to Y.F.) and the Research on Development of New Drugs (to Y.F.) from Japan Agency for Medical Research and Development (AMED); and Grants-in-Aid for Scientific Research from the Ministry of Education, Culture, Sports, Science and Technology of Japan (to Y.F.) and the Japan Society for the Promotion of Science (to Y.F.).

\section{Author contributions}

K.Y., T.U., A.S., Y.T., M.U. and M.W. performed functional, histological and biochemical analyses; K.Y., T.N., M.K.-N., I.T. and M.F. collected patient samples and analysed them;
K.Y., T.U., M.F. and Y.F. contributed to writing the manuscript; Y.F. conceived the project, interpreted the data and wrote the manuscript.

\section{Additional information}

Supplementary Information accompanies this paper at http://www.nature.com/ naturecommunications

Competing financial interests: The authors declare no competing financial interests.

Reprints and permission information is available online at http://npg.nature.com/ reprintsandpermissions/

How to cite this article: Yamamura, K. et al. The transcription factor EPAS1 links DOCK8 deficiency to atopic skin inflammation via IL-31 induction. Nat. Commun. 8, 13946 doi: 10.1038/ncomms13946 (2017).

Publisher's note: Springer Nature remains neutral with regard to jurisdictional claims in published maps and institutional affiliations.

\section{(c) (i)}

This work is licensed under a Creative Commons Attribution 4.0 International License. The images or other third party material in this article are included in the article's Creative Commons license, unless indicated otherwise in the credit line; if the material is not included under the Creative Commons license, users will need to obtain permission from the license holder to reproduce the material. To view a copy of this license, visit http://creativecommons.org/licenses/by/4.0/

(C) The Author(s) 2017 